\title{
Review \\ Alkaloids and Colon Cancer: Molecular Mechanisms and Therapeutic Implications for Cell Cycle Arrest
}

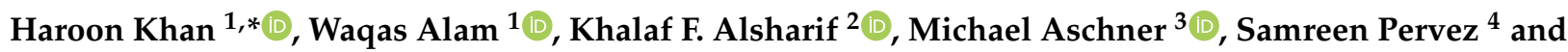 \\ Luciano Saso ${ }^{5}$
}

Citation: Khan, H.; Alam, W.; Alsharif, K.F.; Aschner, M.; Pervez, S.; Saso, L. Alkaloids and Colon Cancer: Molecular Mechanisms and Therapeutic Implications for Cell Cycle Arrest. Molecules 2022, 27, 920. https://doi.org/10.3390/ molecules 27030920

Academic Editors: José Antonio Lupiáñez, Eva E. Rufino-Palomares and Amalia Pérez-Jiménez

Received: 7 December 2021

Accepted: 25 January 2022

Published: 28 January 2022

Publisher's Note: MDPI stays neutral with regard to jurisdictional claims in published maps and institutional affiliations.

Copyright: (C) 2022 by the authors. Licensee MDPI, Basel, Switzerland. This article is an open access article distributed under the terms and conditions of the Creative Commons Attribution (CC BY) license (https:// creativecommons.org/licenses/by/ $4.0 /)$.
1 Department of Pharmacy, Abdul Wali Khan University Mardan, Mardan 23200, Pakistan; waqasalamyousafzai@gmail.com

2 Department of Clinical Laboratory, College of Applied Medical Science, Taif University, P.O. Box 11099, Taif 21944, Saudi Arabia; alsharif@tu.edu.sa

3 Department of Molecular Pharmacology, Albert Einstein College of Medicine, Bronx, NY 10461, USA; michael.aschner@einsteinmed.org

4 Department of Pharmacy, Qurtuba University of Science and Information Technology, Peshawar 29050, Pakistan; samreengcp@gmail.com

5 Department of Physiology and Pharmacology "Vittorio Erspamer", Sapienza University of Rome, 00185 Rome, Italy; luciano.saso@uniroma1.it

* Correspondence: hkdr2006@gmail.com or haroonkhan@awkum.edu.pk

\begin{abstract}
Cancer is the second most fatal disease worldwide, with colon cancer being the third most prevalent and fatal form of cancer in several Western countries. The risk of acquisition of resistance to chemotherapy remains a significant hurdle in the management of various types of cancer, especially colon cancer. Therefore, it is essential to develop alternative treatment modalities. Naturally occurring alkaloids have been shown to regulate various mechanistic pathways linked to cell proliferation, cell cycle, and metastasis. This review aims to shed light on the potential of alkaloids as anti-colon-cancer chemotherapy agents that can modulate or arrest the cell cycle. Preclinical investigated alkaloids have shown anti-colon cancer activities and inhibition of cancer cell proliferation via cell cycle arrest at different stages, suggesting that alkaloids may have the potential to act as anticancer molecules.
\end{abstract}

Keywords: colon cancer; alkaloids; anticancer activity; cell cycle arrest

\section{Introduction}

Cancer is the second most fatal disease in the world, and according to the World Health Organization (WHO), it accounted for approximately 8.2 million deaths and 14 million new victims in 2012 [1]. In 2017, the projected deaths due to different cancers in the United States were 600,920 , with $1,688,780$ newly diagnosed cancer patients. The overall cancer prevalence and death rate was $20 \%$ higher in males than in females [2]. The coronavirus disease 2019 (COVID-19) pandemic impeded cancer detection and therapy in 2020. In 2021, the United States was projected to have 1,898,160 cancer cases and 608,570 cancer-related deaths [3]. Older people, between 85-90 years-of-age, have higher cancer prevalence than younger subjects [4]. The rapid and unmanageable proliferation of abnormal cells leads to cancer origination [5], with abnormalities during cellular division in the mitochondrial genome triggering genetic mutations and cancer progression [4].

Colon cancer (CC) is one of the most prevalent cancers in the world, with the highest prevalence in Black Alaska's Natives and the lowest prevalence in Asian/Pacific Islanders [6]. Colorectal cancer (CRC) is the most prevalent cancer in Saudi men, and the third most prevalent disease in Saudi women [7]. The American Cancer Society has drafted guidelines for the treatment of colon cancer as well as survivorship care, which include long-term complications from chemotherapy [8-10].

While diagnostic and treatment options for colon cancer have been stipulated [11-13], their outcomes are not always satisfactory, and the number of deaths remains high. Colon 
cancer is the third most prevalent type of cancer, concerning both cases and deaths in the USA [14]. Even though synthetic drugs are currently available, they suffer from low efficacy and adverse side effects, which has led to treatment failure and/or low patient compliance $[15,16]$. Along with drug treatments, diet and physical exercise may also offer treatment $[17,18]$.

Monoclonal antibodies and small-molecule inhibitors are used in targeted therapeutics and are regarded as a viable therapy alternative. Chemotherapy has been the most prevalent treatment of CC; nevertheless, various limitations, such as limited specificity, inappropriate biodistribution, and poor pharmacokinetic profile, often compromise its effectiveness. As a result, researchers have searched for novel chemotherapeutic drugs that are both highly safe and efficacious [19].

Natural products from medicinal plants have been previously used in the treatment of several diseases [20-27]. Among these natural products, alkaloids are one of the most diverse and extensively investigated classes of compounds [28-31]. Alkaloids have been shown to possess antiplatelet [32], antioxidant [33,34], antinociceptive [35], antipyretic [36], antiasthmatic [37], anticancer [38], and antibacterial effects [38,39] and to inhibit acetylcholinesterase (AChE) and angiotensin-converting enzyme(ACE) inhibition [40].

In this review, we have summarized and focused on the anticancer potentials of various plant-derived alkaloids against colon cancer that could be translated into clinically beneficial agents with a well-defined mechanism-cell cycle arrest.

\section{Cancer Treatment-Alkaloids}

Extracts and alkaloids isolated from plants have shown a role in the suppression of oncogenesis [41,42]. Alkaloids have demonstrated an effect on the regulation of various mechanistic pathways involved in proliferation, cell cycle, and metastasis, thereby attracting considerable attention $[43,44]$. From a clinical perspective, vincristine and vinblastine have historical importance as anticancer agents and are clinically used in the treatment of acute lymphoblastic leukemia [45]. Antitumor drugs, such as vincristine, vinblastine, and paclitaxel, which are being utilized in clinical practice, can exist naturally. Additionally, vincristine or vinblastine treatment has been shown to limit cancer growth in the majority of patients with complicated hemangiomas [46]. These botanicals act through multiple mechanisms and have shown efficacy in breast, ovarian, non-small cell lung, and prostate cancers [47-49]. Berberine (BBR), a fully natural isoquinoline alkaloid obtained from various botanical groupings, has recently attracted attention. Berberine has been shown to be beneficial for immunotherapy by acting as a dopamine receptor antagonist and suppressing the release of Interferon gamma (IFN- $\gamma$ ), Tumor Necrosis Factor-alpha (TNF- $\alpha$ ), Interleukin-1 beta (IL-1 $\beta$ ) and Interleukin-6 (IL-6) from LPS-activated cells. BBR has been shown to inhibit tumor proliferation, to induce autophagy and apoptosis, and to suppress metastasis and angiogenesis [50].

\section{Cell Cycle Arrest in Cancer Treatment}

Cell cycle arrest is a dynamic and versatile mechanistic pathway that has been implicated in the pathophysiology of various human systems [51,52], and which is characterized by several cell cycle checkpoints (G1, S, G2, M) [53,54], especially at the transitions from the G1 phase to the $S$ phase, and from the G2 phase to the M phase $[55,56]$.

\subsection{G1-Phase Arrest}

During the G1 phase, cells prepare for entry into the cell cycle, and duplicate their DNA in the S phase [57,58]. The Gap 1 (G1) checkpoint controls the DNA status and cellular activities and controls DNA replication in the synthesis phase (Sphase) $[59,60]$. The regulatory gene BDE-47 has been shown to cause marked attenuation in cell proliferation targeting the G1 phase [61] by modulating p53 and p21 expression, which in turn regulated cyclinD1 and CDK2. The overall process is influenced by Dux4 stimulation, whichcausesp21 mRNA and protein expression and cell cycle arrest through G1 phase arrest [62]. The S 
transcription in the G1 phase is strongly associated with the transcription factors of E2F coupled with their dimerization partner proteins. Researchers have found functional regulation factors of E2F in cancer $[63,64]$, suggesting that G1-S transcription is critical in the development and proliferation of cancer [65-67].

\subsection{G2-Phase Arrest}

The S phase is followed by the Gap 2 (G2) phase, characterized by a synthesis / repair phase coupled with the preparation of cellular machinery for mitosis in the M (mitosis) phase $[68,69]$. The chromatids and daughter cells separate during the $M$ phase. Subsequently, the cells enter theG1 or G0. The quality and rate of overall cell division is modulated by these checkpoints [70,71]. In this phase, the cdc2-B1 complex is regulated via the activation of phosphate by the Cdk-activating enzyme and the inhibition of phosphatase enzymes [72]. The phosphatase Cdc25C caused dephosphorylation and hence overexpression of Cdk [73-75].

The dormant cells are activated by external stimuli [76]. These growth-promoting factors bind to cell receptors and trigger the cellular machinery [77]. Moreover, genetic intervention has been observed as the focusing target of these growth-modulating factors [78]. The response is designated as earlier and delayed. The former induces phosphorylation and activation of the transcription factor proteins that are already present in the cell. In fact, the genes that are involved in early response encode transcription factors, and ultimately modulate the expression of late response genes. The delayed response genes modulate the proteins, G1 cyclin-dependent kinases (CDKs) [79,80], and therefore CDK inhibitors have recently attracted considerable attention as anticancer agents, especially the CDK4 and CDK6 inhibitors [81,82].

\section{Activity of Alkaloids against Colon Cancer}

In 2001, Ogasawara et al. reported on the anticancer activity of evodiamine $\mathbf{1}$ (Table 1), a quinolone alkaloid, isolated from the fruits of Evodia rutaecarpa, a traditional Chinese medicinal plant. This alkaloid caused a 70\% reduction in the formation of lung metastases induced by colon carcinoma $26-\mathrm{L} 5$ cells in mice $(10 \mu \mathrm{g} / \mathrm{mL}$ in $48 \mathrm{~h})$. Likewise, Zhao et al. and Huang et al. reported multiple mechanisms of colon-cancer inhibition induced by this alkaloid.

Isostrychnopentamine (ISP) 2 is an indolomonoterpenic alkaloid present in the leaves of Strychnos usambarensis, an African shrub. Frédérich et al. (2002) demonstrated the anticancer activity of this alkaloid against HCT-116 and HCT-15 human colon cancer cells. In both cases, ISP caused cell death $\left(\mathrm{IC}_{50}=7.0 \mu \mathrm{M}\right.$ for HCT-116 and $\mathrm{IC}_{50}=15.0 \mu \mathrm{M}$ for HCT-15), promoting cell cycle arrest in the G2-M phase and inducing different pathways of apoptosis. Four years later, Jiao et al. (2006) isolated and identified chaetominine 3 from Chaetomium sp., an endophytic fungus present on the leaves of Adenophora axilliflora. Compound 3 was active against SW-116 colon cancer cells with an $\mathrm{IC}_{50}$ value of $28.0 \mathrm{nM}$.

Shoeb et al. (2006) demonstrated the antiproliferative activity of a unique, dimeric indole alkaloid isolated from the seeds of Centaura montana, named montamine 4 . This alkaloid showed significant activity against $\mathrm{CaCO}_{2}$ cells $\left(\mathrm{IC}_{50}=43.9 \mu \mathrm{M}\right)$, whereas its monomer, moschamine 5, showed an $\mathrm{IC}_{50}$ value of $81.0 \mu \mathrm{M}$.

Koduru and co-researchers (2007) isolated steroidal alkaloids, named as tomatidine 6 and solasodine 7, from Solanum aculeastrum (Figure 1) [83]. Sanguinarine 8, a benzophenanthridine alkaloid isolated from the roots of Sanguinaria canadensis, evoked a significant anticancer effect [84]. Subsequently, in 2012, Lee et al. reported other work about the antiproliferative activity of this alkaloid [85]. 


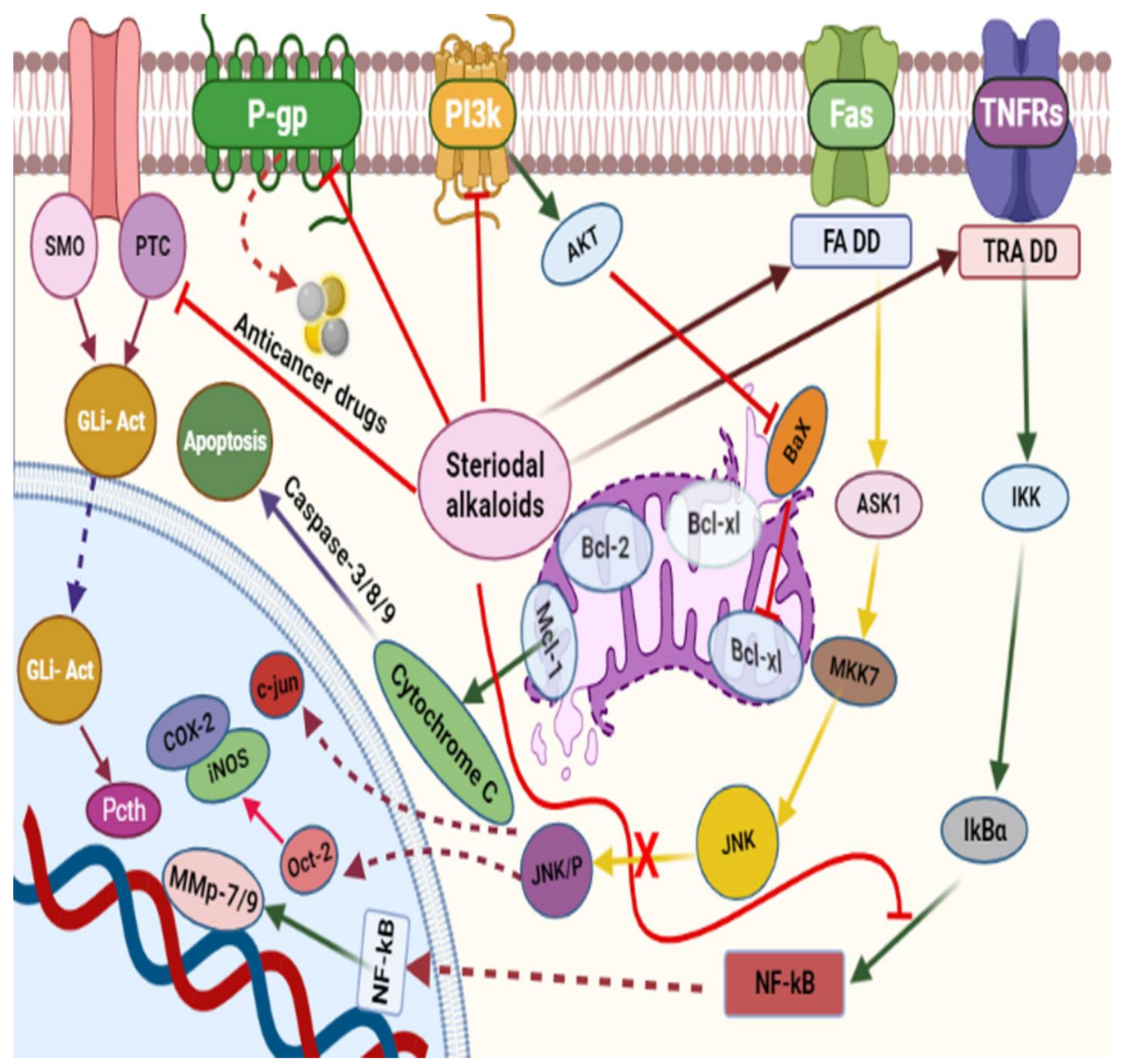

Figure 1. Schematic representation of molecular mechanisms of action involved in anticancer effect of steroidal alkaloids in colonic cancer. Steroidal alkaloids inhibit different pathways such aspg-p, PI3k, Fas, and TNRfs, which are, in turn, linked with different mechanistic pathways exhibiting anticancer effects. Inhibition of Bax and Bcl2 leads to activation of caspase-3,8, and 9 pathways, thus leading to apoptosis. 
Table 1. Plant-derived alkaloids with anticancer effects in colon cancer.

\section{Plant Species}

Strychnos usambarensis

Chaetomium sp.

\section{Alkaloids with Structure and Potency}

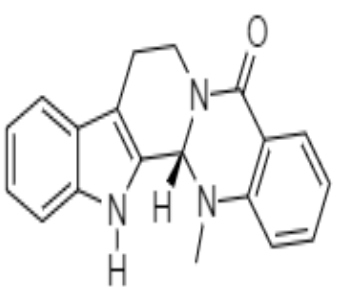

$1\left(\mathrm{IC}_{70}: 10 \mu \mathrm{g} / \mathrm{mL}\right)$

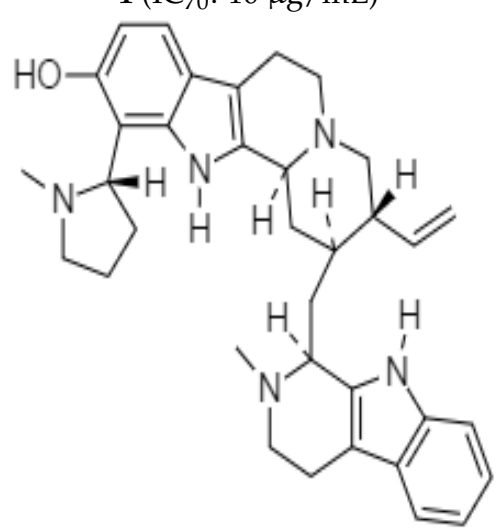

$2\left(\mathrm{IC}_{50}: 7.0-15 \mu \mathrm{M}\right)$

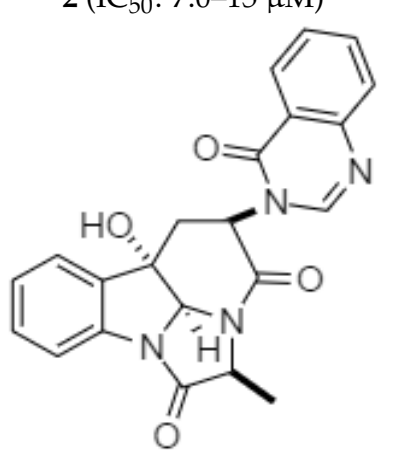

$3\left(\mathrm{IC}_{50}: 28.0 \mathrm{nM}\right)$
Reference

[86]

[87] 
Table 1. Cont.<smiles>COc1cc(/C=C/C(=O)N(CCc2c[nH]c3ccc(O)cc23)N(CCc2c[nH]c3ccc(O)cc23)C(=O)/C=C/c2ccc(O)c(OC)c2)ccc1O</smiles>

$4\left(\mathrm{IC}_{50}: 43.9 \mu \mathrm{M}\right)$<smiles>[H][Y]([H])(CCc1c[nH]c2ccc(O)cc12)N([2H])C(=O)/C=C/c1ccc(O)c(OC)c1</smiles>
$5\left(\mathrm{IC}_{50}: 81.0 \mu \mathrm{M}\right)$
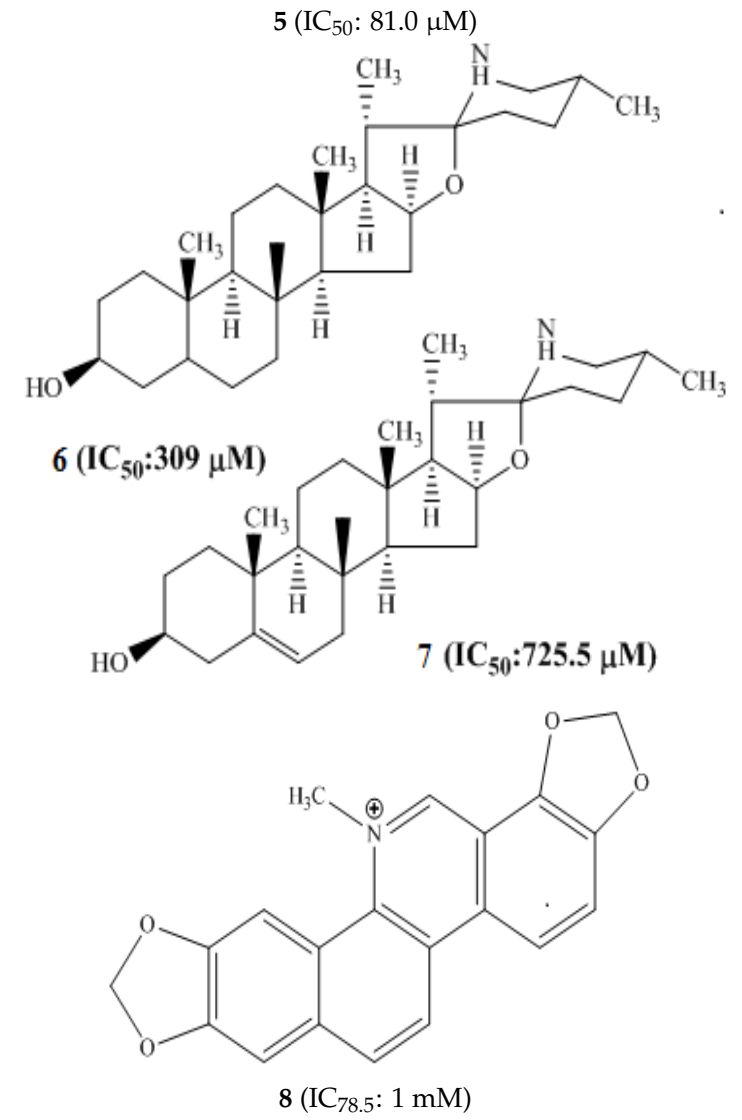
Table 1. Cont.

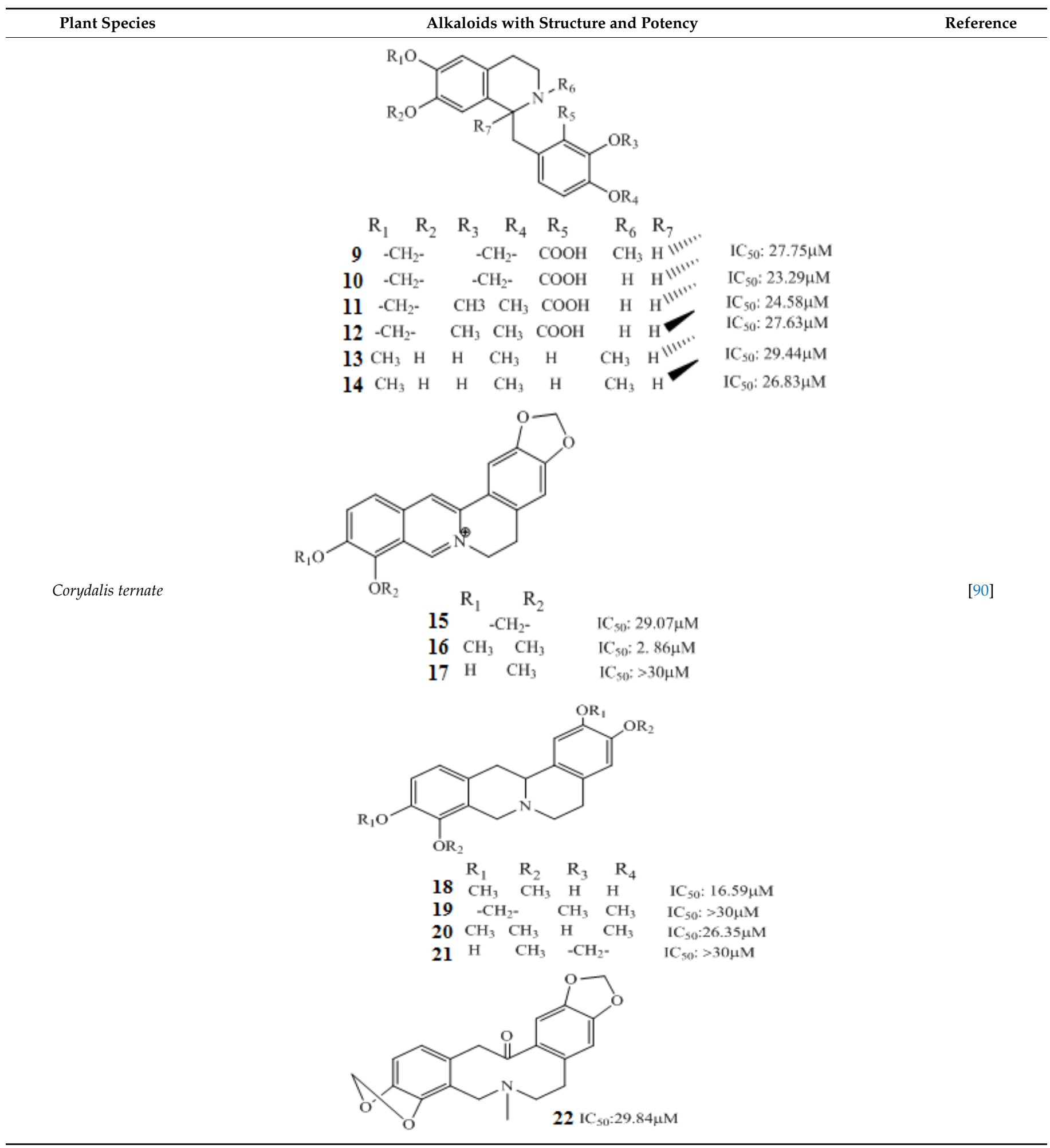


Table 1. Cont.

Menispermum dauricum

Evodia rutaecarpa

Cynanchum paniculatum
Alkaloids with Structure and Potency

Reference

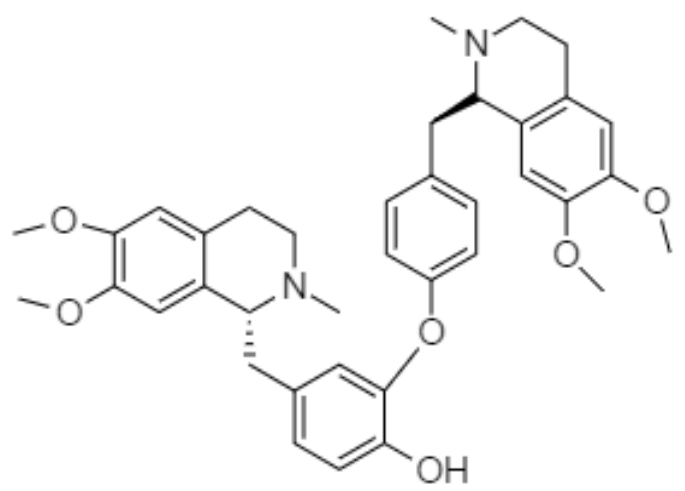

$23\left(\mathrm{IC}_{80}: 10 \mu \mathrm{M}\right)$
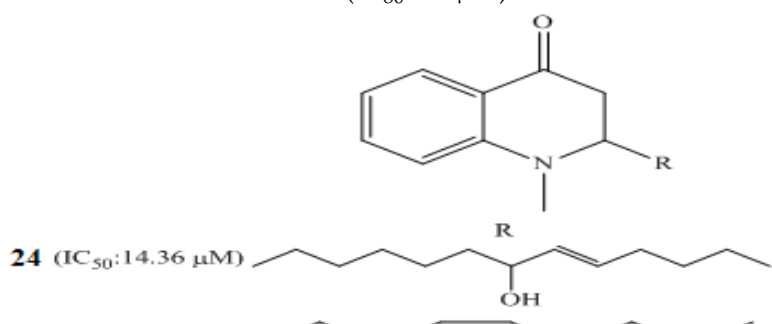

$25\left(\mathrm{IC}_{50}: 21.76 \mu \mathrm{M}\right)$

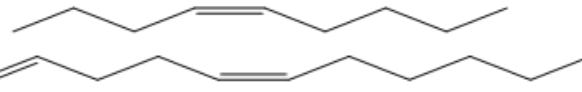

$27\left(\mathrm{IC}_{50}: 21.91 \mu \mathrm{M}\right.$

$28\left(\mathrm{IC}_{50}: 21.92 \mu \mathrm{M}\right)$

$29\left(\mathrm{IC}_{50}: 19.45 \mu \mathrm{M}\right)$
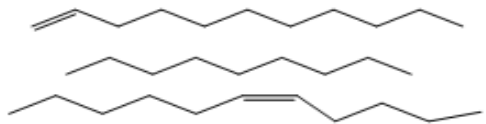

$30\left(\mathrm{IC}_{50}: 19.83 \mu \mathrm{M}\right)$

$31\left(\mathrm{IC}_{50}: 18.14 \mu \mathrm{M}\right)$

$32\left(\mathrm{IC}_{50}: 19.75 \mu \mathrm{M}\right)$

$33\left(\mathrm{IC}_{50}: 16.52 \mu \mathrm{M}\right.$

$34\left(\mathrm{IC}_{50}: 20.38 \mu \mathrm{M}\right)$

$35 .\left(\mathrm{IC}_{50}: 19.90 \mu \mathrm{M}\right)$

$36\left(\mathrm{IC}_{50}: 15.32 \mu \mathrm{M}\right)$

$37\left(\mathrm{IC}_{50}: 16.83 \mu \mathrm{M}\right.$

$38\left(\mathrm{IC}_{90}: 15.90 \mu \mathrm{M}\right)$

39 (IC $50: 15.90 \mu \mathrm{M})$

40 (IC sni:15.95 uM
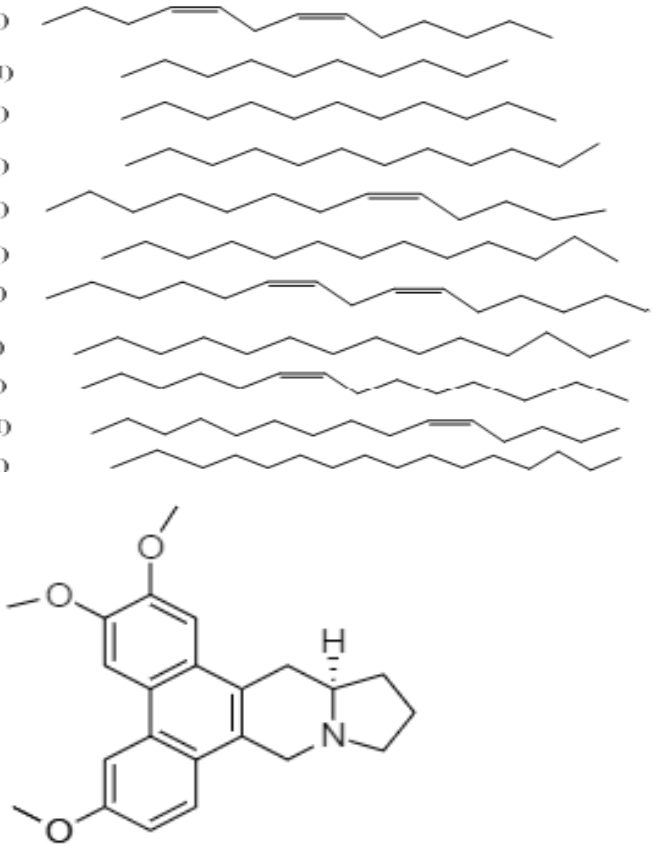

$41\left(\mathrm{IC}_{50}: 4.7-10.8 \mathrm{nM}\right)$
[91] 
Table 1. Cont.

Plant Species

Zanthoxylum capense

Acorus gramineus

Tabernaemontana corymbosa
Alkaloids with Structure and Potency

Reference<smiles>COc1c(O)cc2c3c(O)c(O)cc(c13)CC2</smiles><smiles>COCCOc1ccccc1O</smiles><smiles>COCCOC</smiles>

43

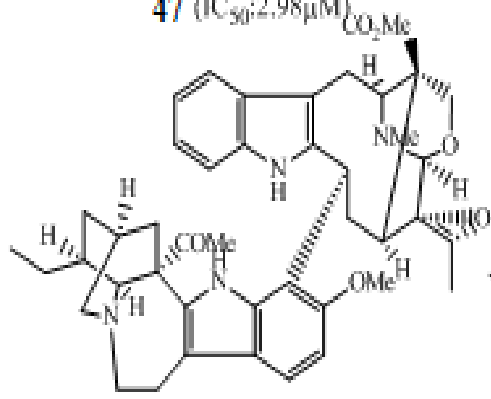

$49\left(\mathrm{IC}_{50}: 14.95 \mu \mathrm{M}\right)$
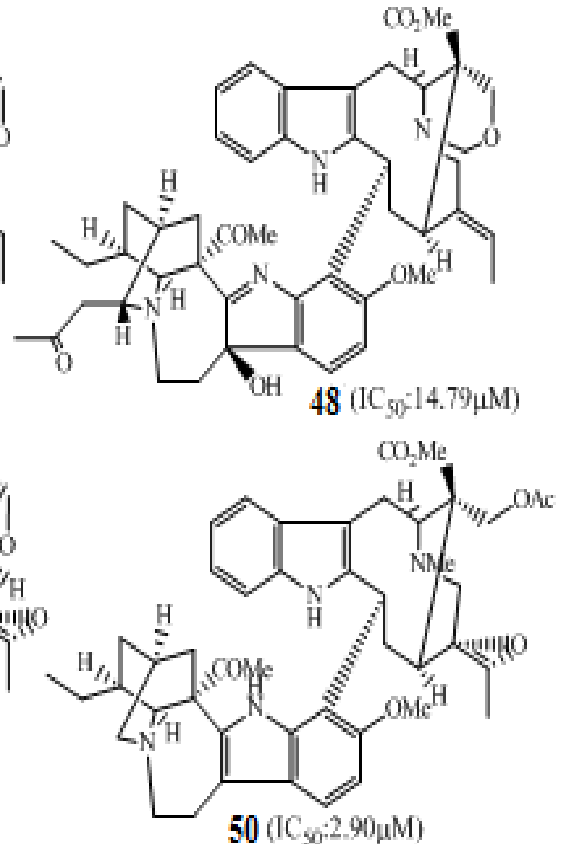
Table 1. Cont.

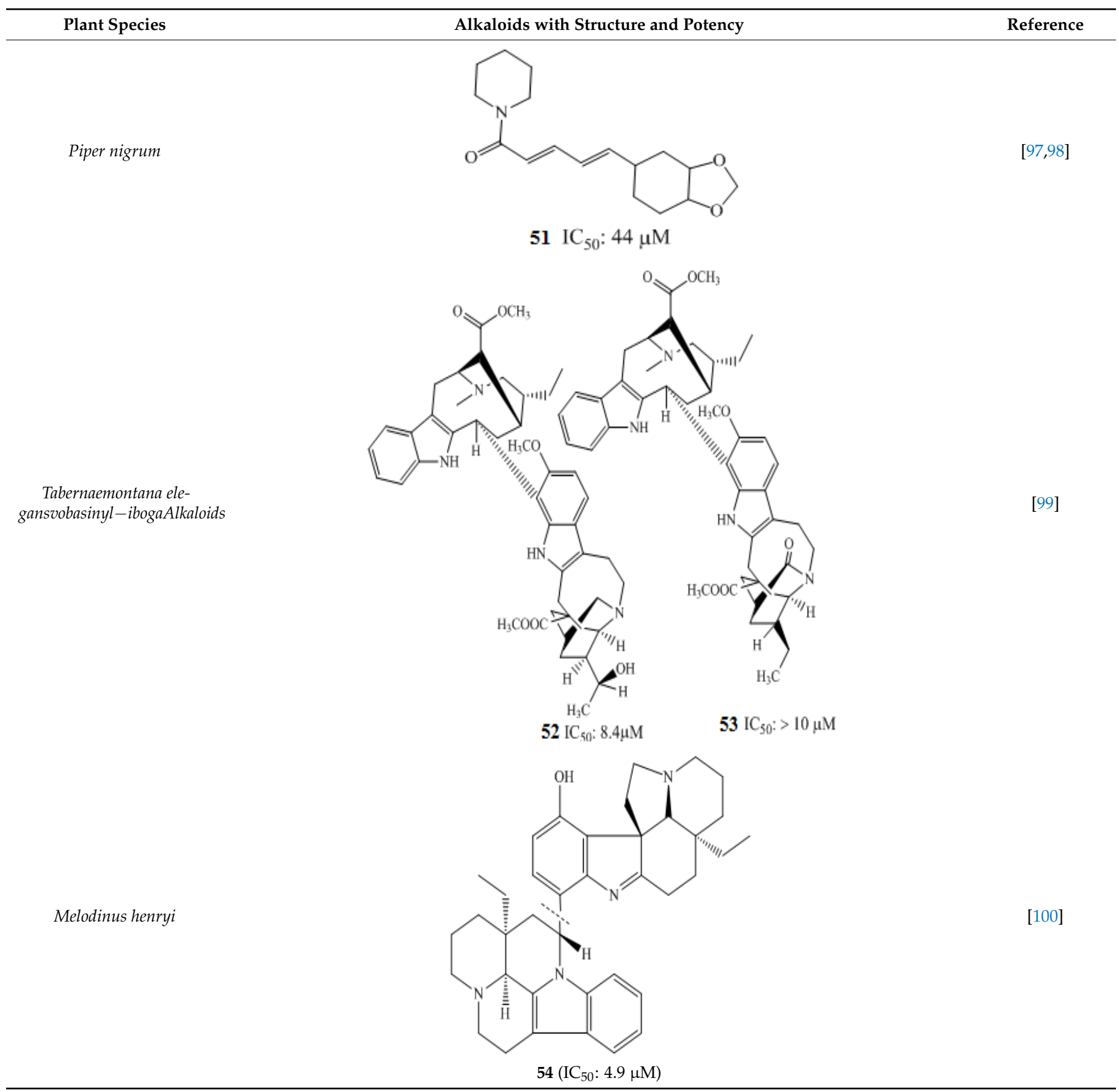


Table 1. Cont.

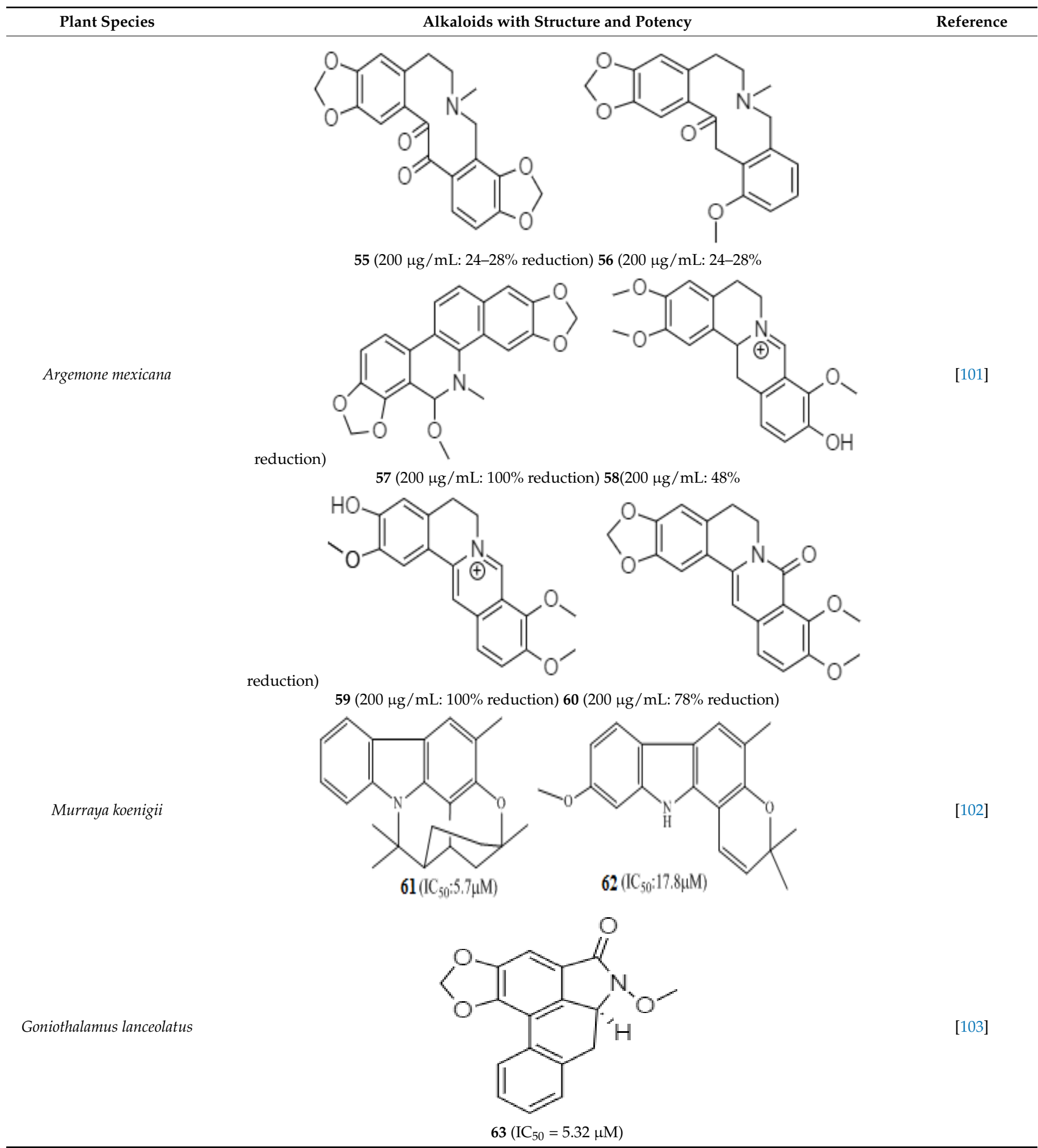

Korean researchers isolated several alkaloids 9-22 from Corydalis ternate phytochemicallyy [90]. These were characterized as epi-coryximine 9, coryternatines A 10, coryternatines B 11, coryternatines C 12, coryternatines D 13, $(S)$-reticuline, $(R)$-reticuline 14, coptisine 15, dimethyl corydalmine 16, tetrahydroberberine 17 , berberine 18, protopine $\mathbf{1 9}$, corydalmine $\mathbf{2 0}$, thalifendine $\mathbf{2 1}$, and cheilanthifoline $\mathbf{2 2}$. When studied for in vitro 
anticancer activity against various cancer cell lines, they showed selective cytotoxicity against human colon cell line, HCT-15.

Yang et al. (2010) demonstrated that dauricine 23 (Table 1), a bisbenzylisoquinoline alkaloid, inhibited four lines of colon cancer cells (HCT-116, HCT-8, SW620, and SW480). The mechanism involved the inhibition of proliferation/invasion and induction of apoptosis by suppressing nuclear factor-kappaB (NF-kB) activation in a dose/timedependent relation. In 2012, investigation of the whole plant of Evodia rutaecarpa by Chinese researchers led to the isolation of 17 quinolone alkaloids. The anticancer studies of these compounds caused marked antiproliferative activity against gastric cell N-87 in vitro assay. These alkaloids are 1-methyl-2-[7-hydroxy-(E)-9-tridecenyl]-4(1H)-quinolone $24\left(\mathrm{IC}_{50}: 16.25 \mu \mathrm{M}\right)$, 1-methyl-2-[(Z)-4-nonenyl]-4(1H)-quinolone $25\left(\mathrm{IC}_{50}: 17.25 \mu \mathrm{M}\right)$, 1-methyl-2-[(1E,5Z)-1,5-undecadienyl]-4(1H)-quinolone 26 (IC 50 : $16.70 \mu \mathrm{M})$, 1-methyl-2[(E)-1-undecenyl]-4(1H)-quinolone $27\left(\mathrm{IC}_{50}: 18.04 \mu \mathrm{M}\right)$, 1-methyl-2-nonyl-4(1H)-quinolone 28 (IC $\left.\mathrm{I0}_{50}: 23.34 \mu \mathrm{M}\right)$, 1-methyl-2-[(Z)-6-undecenyl-4(1H)-quinolone $29\left(\mathrm{IC}_{50}: 18.66 \mu \mathrm{M}\right)$, 1-methyl-2-[(4Z,7Z)-tridecadienyl]-4(1H)-quinolone $30\left(\mathrm{IC}_{50}\right.$ : $\left.17.85 \mu \mathrm{M}\right)$, 1-methyl-2-decyl4(1H)-quinolone 31 ( $\left.\mathrm{IC}_{50}: 21.69 \mu \mathrm{M}\right)$, 1-methyl-2-undecyl-4(1H)-quinolone 32 (IC IC $_{50}: 20.52$ $\mu \mathrm{M})$, 1-methyl-2-dodecyl-4(1H)-quinolone 33 ( $\left.\mathrm{IC}_{50}: 20.82 \mu \mathrm{M}\right)$, evocarpine $34\left(\mathrm{IC}_{50}: 17.25\right.$ $\mu \mathrm{M})$, dihydroevocarpine $35\left(\mathrm{IC}_{50}: 18.18 \mu \mathrm{M}\right)$, 1-methyl-2-[(6Z,9Z)-pentadecadienyl]-4(1H)quinolone $36\left(\mathrm{IC}_{50}: 12.64 \mu \mathrm{M}\right)$, 1-methyl-2-tetradecyl-4(1H)-quinolone $37\left(\mathrm{IC}_{50}: 16.72 \mu \mathrm{M}\right)$, 1-methyl-2-[(Z)-6-pentadecenyl]-4(1H)-quinolone 38 ( $\mathrm{IC}_{50}$ : $\left.14.52 \mu \mathrm{M}\right)$, 1-methyl-2-[(Z)-10pentadecenyl]-4(1H)-quinolone $39\left(\mathrm{IC}_{50}: 14.52 \mu \mathrm{M}\right)$, and 1-methyl-2-pentadecyl-4(1H)quinolone $40\left(\mathrm{IC}_{50}: 14.27 \mu \mathrm{M}\right)$ [92].

Antofine 41, a phenanthroindolizidine alkaloid isolated from the whole plant of Cynanchum paniculatum, showed potent antiproliferative effects in different types of colon cancer cells with $\mathrm{IC}_{50}$ values in the nanomolar range $(6.3 \mathrm{nM}$ on HCT-116, $10.8 \mathrm{nM}$ on HT-29 and $4.7 \mathrm{nM}$ on SW-480). In HCT-116 cells, treatment with antofine induced cell cycle arrest in theG0/G1 phases (Min et al., 2012).

Three other alkaloids 42-44 were isolated from Zanthoxylum capense; when subjected to anticancer activity against HCT-116 colon cancer cells using the Guava ViaCount viability assay at various test concentrations of 5,10,20, and $50 \mathrm{Mm}$, significant effects were observed [94]. These were named after characterization as decarine $\mathbf{4 2}$, norchelerythrine 43 and zanthocapensine 44 . Kim et al. (2015) worked on the isolation of bioactive secondary metabolites from Korean medicinal plants, isolating from Acorus gramineus two alkaloids, gramichunosin 45 and 4-(2-Formyl-5-(methoxymethyl)-1H-pyrrole-1-yl)butanoic acid 46 [95]. When these compounds were studied for anticancer potential against the colon cancer cell line HCT-15, both the alkaloids were found with $\mathrm{EC}_{50}: 45.23$ and $37.23 \mu \mathrm{M}$, respectively.

Zhang and coworkers (2015) isolated four new alkaloids from Tabernaemontana corymbosa, named as tabercorines A-C (47-49) and 17-acetyl-tabernaecorymbosine A 50 [96]. In the results against SW-480 cell lines, tabercorines $A 47\left(\mathrm{IC}_{50}: 9.24 \mu \mathrm{M}\right)$ and 17-acetyltabernaecorymbosine A $50\left(\mathrm{IC}_{50}: 4.70 \mu \mathrm{M}\right)$ were more potent than standard cisplatin $\left(\mathrm{IC}_{50}\right.$ : $11.07 \mu \mathrm{M})$. Yaffe et al. (2015) isolated piperine 51 from Piper nigrum, which exhibited marked anticancer effects against colon cancer cell lines with $\mathrm{IC}_{50}: 44 \mu \mathrm{M}$ [97]. Researchers from Portugal investigated a monoterpene indole alkaloid isolated from Tabernaemontana elegans [99]. Dregamine 52 and tabernaemontanine 53 caused $8.4 \mu \mathrm{M}$ and $>10 \mu \mathrm{M}$, respectively. Liu et al. (2016) isolated melodinineV 54 from Melodinus henryi [100]. When studied against the HT-29 colon cancer cell line, it showed potent anticancer effects with an $\mathrm{IC}_{50}$ value of $4.9 \mu \mathrm{M}$ in vitro. Singh et al. isolated six different alkaloids (13-oxoprotopine 55, protomexicine 56, 8-methoxydihydrosanguinarine 57 , dehydrocorydalmine 58 , jatrorrhizine 59, and 8-oxyberberine 60) from the whole plant of Argemone mexicana and studied them against the SW-480 human colon cancer cell line. Of these test compounds, jatrorrhizine and 8-methoxydihydrosanguinarine caused $100 \%$ cell death after $48 \mathrm{~h}$ at $200 \mu \mathrm{g} / \mathrm{mL}$ [101].

Arun et al. (2017) isolated pyranocarbazole alkaloids from the leaves and flowers of Murraya koenigii, from which murrayazoline $\mathbf{6 1}$ and O-methylmurrayamine A 62 showed 
potent anticancer activity in DLD-1coloncancercells [102], with $\mathrm{IC}_{50}$ values of $5.7 \mathrm{mM}$ and $17.9 \mathrm{mM}$, respectively. An alkaloid isolated from Goniothalamus lanceolatus, namely, goniolanceolactam 63 , showed potent cytotoxicity against the colon cell line with $\mathrm{IC}_{50}$ value of $5.32 \mu \mathrm{M}$ [103]. A schematic representation of molecular pathways of the anticancer effect of steroidal alkaloids in colon cancer is presented in Figure 1.

\section{Activity of Synthetic Derivatives against Colon Cancer}

The summary of the activity of synthetic alkaloid derivatives with potential therapeutic effect in colon cancer is shown in Table 2. The derivative exatecan mesylate ((1S,9S)1-amino-9-ethyl-5-fluoro-2,3-dihydro-9-hydroxy-4-methyl-1 $H, 12 H$-benzo(de) pyrano $\left(3^{\prime}, 4^{\prime}\right.$ 6,7)indolizino(1,2-b)quinoline-10,13(9H,15H)dionemethanesulfonate) 64 from camptothecin, a quinoline indole alkaloid with antiproliferative activity, was investigated by Hattum et al. (2002) for anticancer activity against several colon cancer cell lines (COLO205-IC 50 :

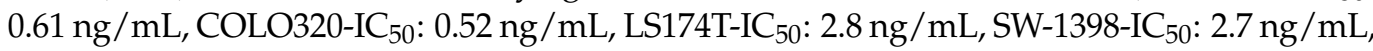
and $\mathrm{WiDr}_{-} \mathrm{IC}_{50}: 7.5 \mathrm{ng} / \mathrm{mL}$, for in vitro activity). The activity was also observed in an in vivo model, and this derivative was considered more potent than topotecan and SN-38 [104].

In 2007, Italian researchers synthesized nortopsentin analogues of marine alkaloids, such as 3,5-bis(3'-indolyl)pyrazol 65 and 1-chloro-3,5-bis( $3^{\prime}$-indolyl)pyrazol 66, earlierisolated from Spongosorites (Table 2). These analogues showed activity against several colon cancer cells (COLO-205: $\mathrm{GI}_{50}=7.98$ and $2.22 \mu \mathrm{M}$, respectively; HCC-2998: 4.74 and $1.71 \mu \mathrm{M}$; HCT-116: 19.0 and $3.82 \mu \mathrm{M}$; HCT-15: 8.68 and 3.01 $\mu \mathrm{M}$; HT-29: 5.35 and $3.57 \mu \mathrm{M}$; KM-12: 4.58 and $3.45 \mu \mathrm{M}$; and SW-620:>100 and $3.52 \mu \mathrm{M})$. The analogue 1-chloro-3,5-bis( $3^{\prime}$-indolyl) pyrazol, bearing a chloro group, was more active both in terms of $\mathrm{GI}_{50}$ and of percentage of sensitive cell lines. Plakinamines $\mathrm{N}$ and $\mathrm{O}$, two additional steroidal alkaloids from Corticium niger, as well as two established plakinamine compounds, were isolated $(3,4)$. Using a combination of MS and NMR spectroscopic data, the structures of these molecules were characterized. The antineoplastic effectiveness of plakinamines $\mathrm{N}, \mathrm{O}$, and J was examined in the NCI-60 screen, and they demonstrated improved inhibitory activity against all colorectal cell cultures [105].

Table 2. Synthetic alkaloid derivatives with potential in colon cancer.

Sources Derivatives


Table 2. Cont.

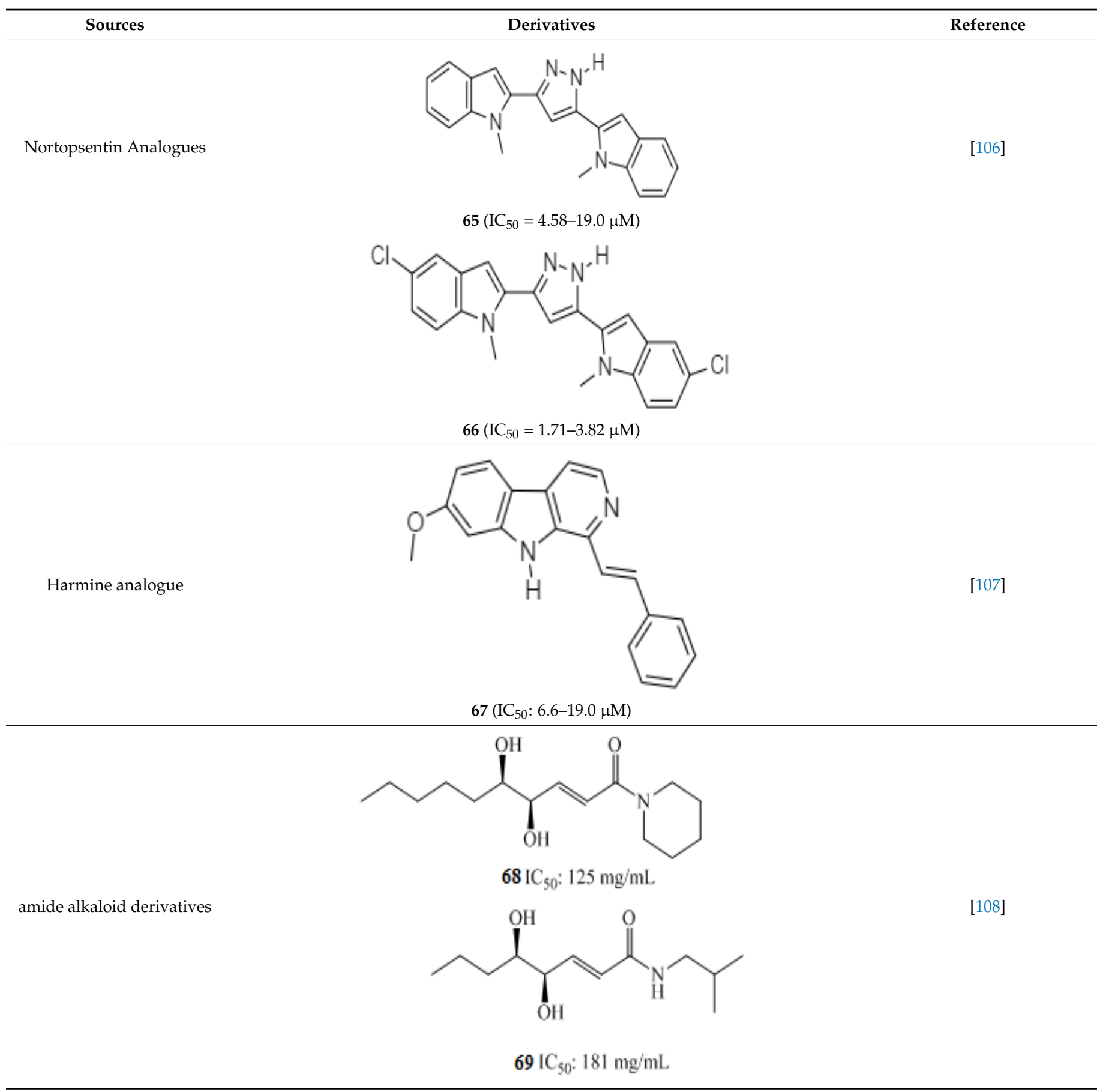


Table 2. Cont.

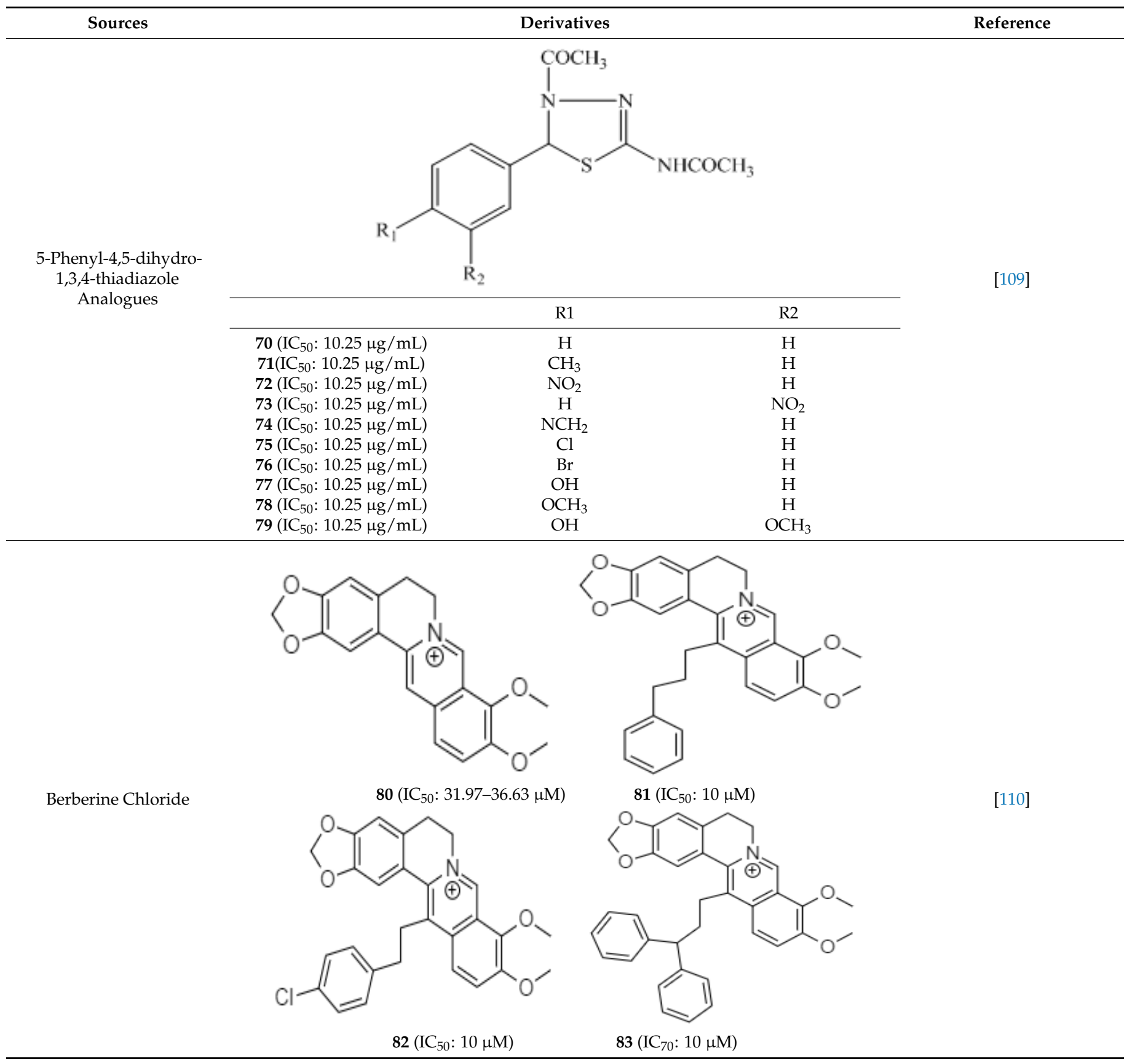


Table 2. Cont.

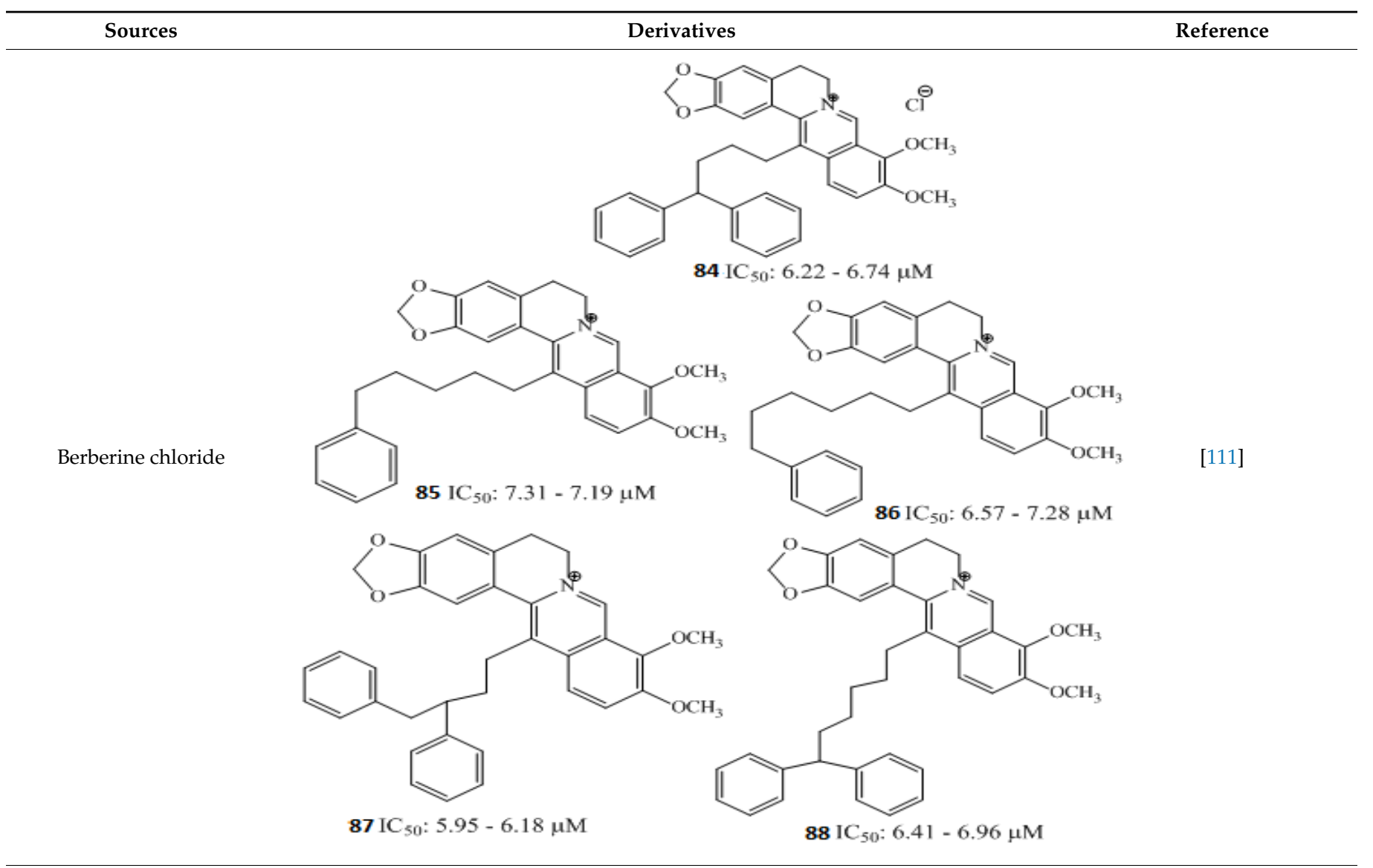

Dregamine and Tabernaemontamine
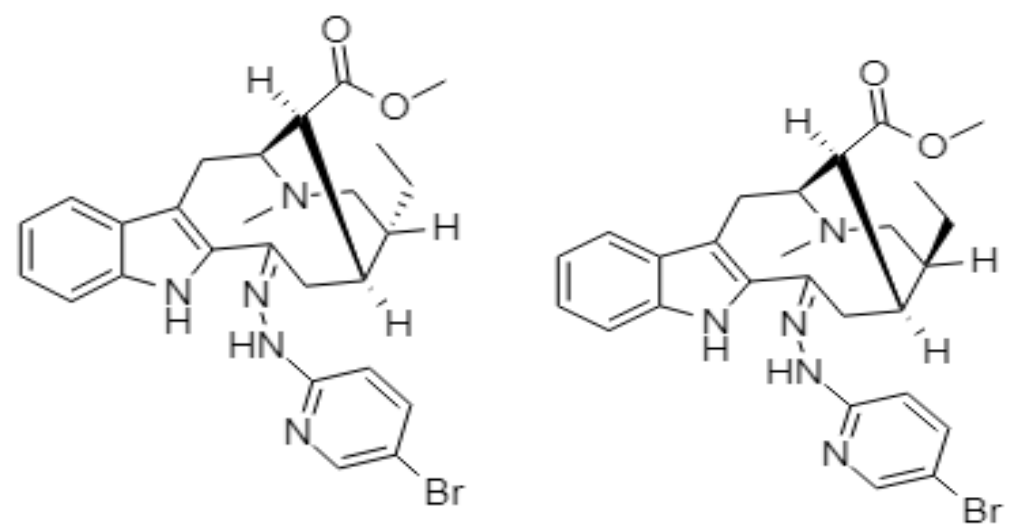

89 (IC $95: 25 \mu \mathrm{M})$

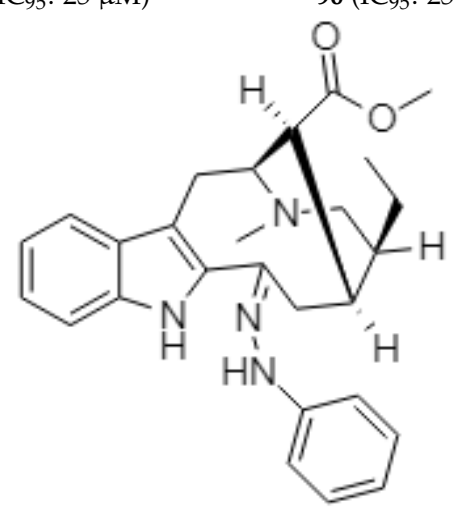

$91\left(\mathrm{IC}_{95}: 50 \mu \mathrm{M}\right)$ 
Table 2. Cont.

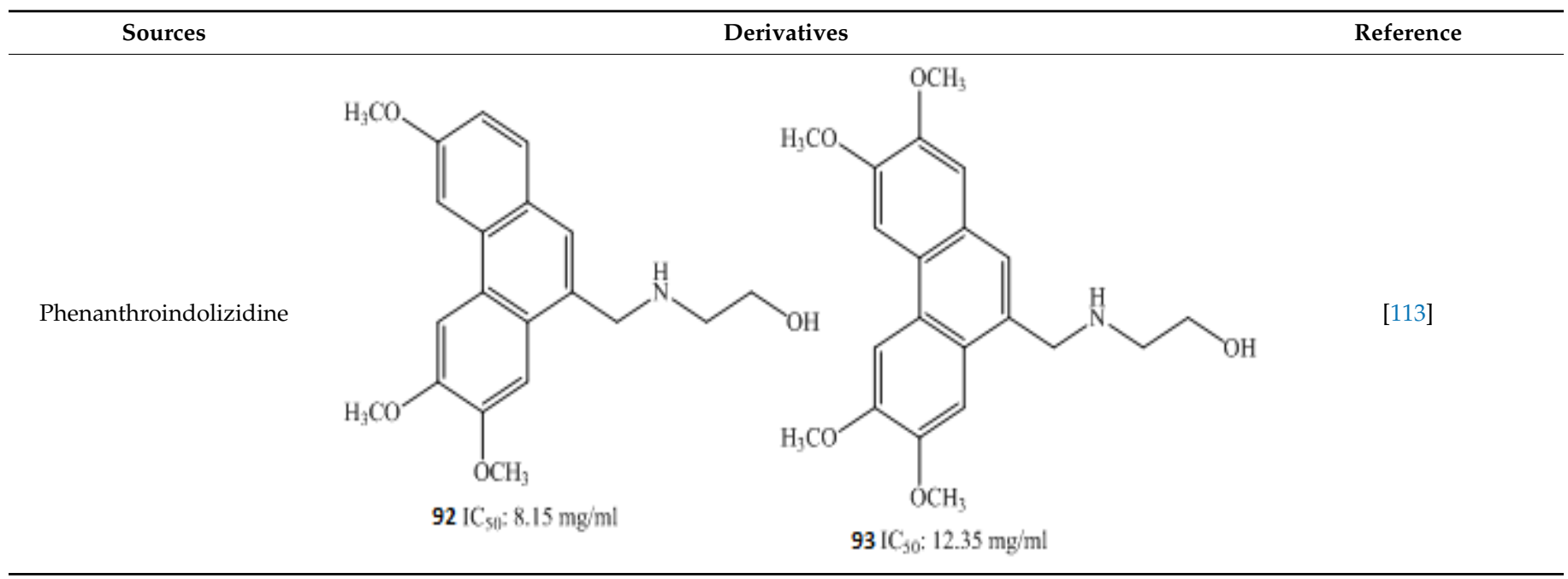

Luo et al. investigated the anticancer effect of JKA97 (methoxy-1-styryl-9H-pyrid-[3,4-b]indole) 67 , a benzylidene analogue of alkaloid harmine. This synthetic substance inhibited human colon cancer HCT-116 cells by apoptotic induction via p53-independent mechanisms. The authors demonstrated that JKA97-induced apoptosis was impaired in Bax knock-out $\left(\mathrm{Bax}^{-/-}\right)$HCT-116 cells. In addition, JKA97 also showed significant apoptotic activity against another human colon cancer cell line with p53 mutations (SW-620).Srinivas et al. (2009) synthesized amid alkaloids which were characterized as $(4 R, 5 R)-2 E-4,5$-dihydroxy-1-(piperidin-1yl)dec-2-en-1-one 68 and $(4 R, 5 R)-2 E-4,5$-dihydroxy- $N$-isobutyloct-2-enamide 69 [108].

These stereoselective amid alkaloids exhibited a marked anticancer effect against HT29 colon cell lines with 125 and $181 \mu \mathrm{g} / \mathrm{mL}$, respectively. Similarly, several 5-Phenyl-4,5dihydro-1,3,4-thiadiazole derivatives were synthesized by Alam and colleagues. These include $N$-(4-Acetyl-5-phenyl-4,5-dihydro-1,3,4-thiadiazol-2-yl)acetamide 70, N-(4-Acetyl5-p-tolyl-4,5-dihydro-1,3,4-thiadiazol-2-yl)acetamide 71, N-(4-Acetyl-5-(4-nitrophenyl)-4,5dihydro-1,3,4-thiadiazol-2-yl)-acetamide 72, N-(4-Acetyl-5-(3-nitrophenyl)-4,5-dihydro-1,3,4thiadiazol-2-yl)-acetamide 73, N-(4-Acetyl-5-(3-(dimethylamino)phenyl)-4,5-dihydro-1,3,4thiadiazol-2-yl)acetamide 74, N-(4-Acetyl-5-(4-chlorophenyl)-4,5-dihydro-1,3,4-thiadiazol-2yl)-acetamide 75, N-(4-Acetyl-5-(4-bromophenyl)-4,5-dihydro-1,3,4-thiadiazol-2-yl)-acetamide 76, N-(4-Acetyl-5-(4-hydroxyphenyl)-4,5-dihydro-1,3,4-thiadiazol-2-yl)-acetamide 77, N-(4Acetyl-5-(4-methoxyphenyl)-4,5-dihydro-1,3,4-thiadiazol-2-yl)-acetamide 78, and N-(4-Acetyl5-(4-hydroxy-3-methoxyphenyl)-4,5-dihydro-1,3,4-thiadiazol-2-yl)acetamide 79 [109].

Berberine $\mathbf{8 0}$ is a highly studied isoquinoline plant alkaloid isolated from many species of the genus berberis [114]. Italian researchers synthesized a number of berberine $\mathbf{8 0}$ derivatives, which were characterized as [13-(3-phenylpropyl)-9,10-dimethoxy-5,6-dihydrobenzo [g]-1,3benzojiokisoro [5,6-a] quinolizinium iodide] 81, [13-[2-(4-chlorophenyl) ethyl]-910-dimethoxy5,6-dihydrobenzo [g]-1,3-benzojiokisoro [5,6-a] quinolizinium iodide] 82, [13-(3,3-diphenylpropyl)-9,10-dimethoxy-5,6-dihydrobenzo[g]-1,3-benzojiokisoro [5, 6-a] quinolizinium iodide] 83, [13-(4,4-diphenylbutyl)-9,10-dimethoxy-5,6-dihydrobenzo[g]-1,3-benzodioxolo [5,6a]quinolizinium chloride] 84, [13-(5-phenylpentyl)-9,10-dimethoxy-5,6-dihydrobenzo[g]-1,3benzodioxolo[5,6-a]quinolizinium chloride] 85, [13-(6-phenylhexyl)-9,10-dimethoxy-5,6dihydrobenzo[g]-1,3-benzodioxolo[5,6-a]quinolizinium chloride] 86, [13-(5,5-diphenylpentyl)9,10-dimethoxy-5,6-dihydrobenzo[g]-1,3-benzodioxolo[5,6-a]quinolizinium chloride] 87 and [13-(6,6-diphenylhexyl)-9,10-dimethoxy-5,6-dihydrobenzo[g]-1,3-benzodioxolo[5,6-a]quinolizinium chloride] 88. Compounds 81, 82, and 83 were active against HCT-116 and SW-613-B3 cells. The evaluation of cell survival by a DNA release-based assay revealed that $10 \mu \mathrm{M}$ NAX012 produced an inhibitory effect on HCT-116 cell survival (40\%) and enhanced during the recovery time (50\%). NAX014 induced a cell growth inhibition of approximately $30 \%$, 
which increased to about $50 \%$ with the recovery time, whereas NAX018 demonstrated a cytotoxic effect after the treatment in about 50\%, reaching 70\% after the recovery time. InSW-613-B3 cells, the incubation with $10 \mu \mathrm{M}$ NAX012 and NAX014 was not effective, while NAX018 affected cell survived by $10 \%$ and $20 \%$ (at the completion of incubation and after the recovery response, respectively).In particular, when compared to the lead compound BBR, these derivatives showed high potency, being more effective in cells harboring p53wt, promoting cell cycle arrest and DNA damage, and triggering caspase-dependent apoptosis and autophagy [111]. Ilyas and his coauthors established the anticancer efficacy of doxorubicin (of synthetic origin) combined with berberine (of natural origin)by applying an encapsulation/conjugation approach with poly (lactic-co-glycolic acid) PLGA nanoparticles. By using carbodiimide chemistry, doxorubicin has been effectively conjugated to PLGA, and the PLGA-doxorubicin conjugate (PDC) was employed to encapsulate berberine. ROS analysis demonstrated that the PDBNP depicted a dose-dependent rise in the reactive oxygen species (ROS) patterns in MDA-MB-231 cells, but no improvement in ROS was detected in T47D cells. PDBNP caused a change (depolarization) in mitochondrial membrane permeability as well as a cell cycle arrest in the sub-G1 phase, whilst Annexin V/PI assay, followed by confocal microscopy, revealed that MDA-MB-231 cells died due to necrosis.

Paternaet al. (2015) synthesized derivatives from monoterpene-indole alkaloid hydrazone and evaluated their activity against HCT-116 colon cancer. The derivatives containing the 5-bromo-pyridine (dregamine 5-bromo-pyridin-2-ylhydrazone 89 and tabernaemontanine 5-bromo-pyridin-2-ylhydrazone 90) ring were the most cytotoxic, reducing cell viability by over $95 \%$ at $25 \mu \mathrm{M}$. The derivative tabernaemontanine phenylhydrazone 91 reduced cell viability to the same level at $50 \mu \mathrm{M}$.

Similarly, a Chinese research group synthesized phenanthroindolizidine, which was characterized as 2-(((3,6,7-trimethoxyphenanthren-9-yl)methyl)amino)ethanol 92 and 2(((2,3,6,7-tetramethoxyphenanthren-9-yl)methyl)amino)ethanol 93. These compounds exhibited potent effects against the colon cancer cell line HT-29 [113].

\section{Effect of Alkaloids on Cell Cycle Arrest and Other Anticancer Pathways}

The anticancer effect of alkaloids and the mechanistic pathways involved in the anticancer effect of alkaloids are schematically represented in Figure 2. Piperine 51, an alkaloid commonly isolated from black pepper [98], mediated its anticancer effect via modulation of G1-phase cell cycle arrest and by downstream regulation of cyclins D1 and D3, accompanied by their activating cofactors, cyclin-dependent kinases 4 and 6 . Piperine caused downstream expression of phosphorylation of retinoblastoma protein and upstream modulation of p21/WAF1 and p27/KIP1 expression (Figure 2) [97]. The G1 expression for the initiation of $\mathrm{Rb}$ protein phosphorylation shape D-type cyclin complexes with Cdk4 and Cdk6 [115,116].On the other hand, to expresses cell cycle progression, it caused inhibition of cyclin-dependent kinases when this complex attached to p21/WAF1 and p27/KIP1, an inhibitor of cyclin-dependent kinases $[117,118]$. 


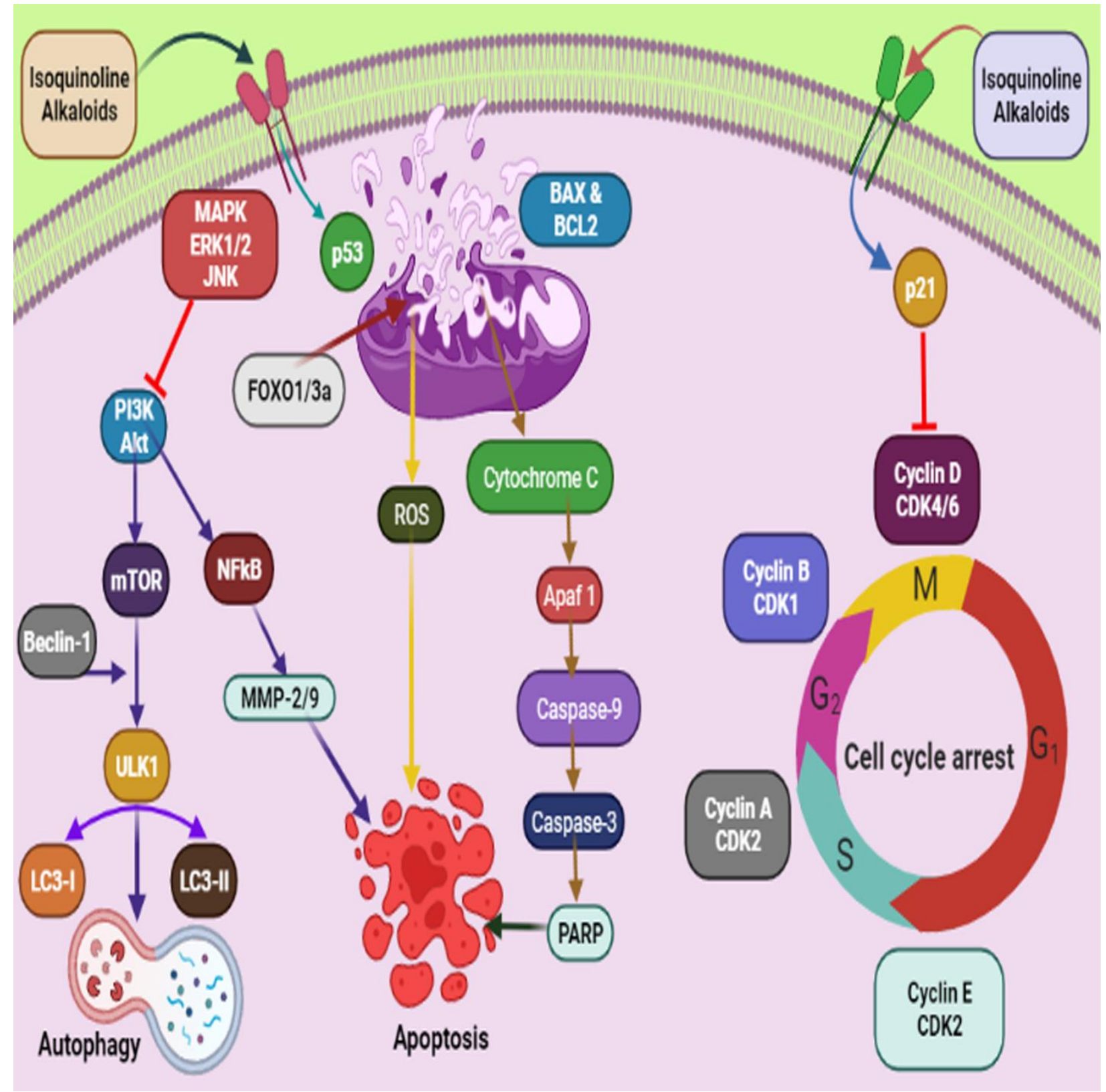

Figure 2. Schematic representation of mechanistic pathways involved in the anticancer effect of alkaloids. Isoquinoline alkaloids exhibit anticancer effect via activating caspase pathway leading to apopstosis. P53 activates different pathways, such as activating ROS, Caspase and inhibiting PI3k. Isoquinoline alkaloids also inhibit Cyclin D CDK 4/6 and causes cell cycle arrest. mTOR pathway is also activated, which leads to autophagy.

The African medicinal plant Tabernaemontana elegans yielded obasinyl-iboga alkaloids dregamine 52, and tabernaemontanine 53 exhibited significant antiproliferative activity by modulating its effect through G1-phase arrest in colon cancer cell lines with associated downstream regulation in the S phase [99]. Arun et al. (2017) studied the effect of pyranocarbazole alkaloids, murrayazoline compound 61 , and $O$-methylmurrayamine A compound 62 in different stages of the cell cycle; both caused significant cell arrest at the $\mathrm{G} 2 / \mathrm{M}$ checkpoint and promoted sub-diploid population at $5.7 \mu \mathrm{M}$ and $17.9 \mu \mathrm{M}$, respectively [102].

The synthetic phenanthroindolizidine alkaloids (92 and 93) showed strong anticancer action by modulating multiple singling pathways. These compounds at a low concentration 
( $5 \mu \mathrm{g} / \mathrm{mL}$ ) elicited cell cycle arrest, while targeting the $\mathrm{G} 2 / \mathrm{M}$ phase. Moreover, a noticeable reduction in cell distribution was observed at the G0/G1 and S phases. In addition, Min et al. (2012) described the effects of another phenanthroindolizidine alkaloid, antofine 41, in HCT-116 cells, causing cell cycle arrest at the G0/G1 phases and inhibiting the expression of cyclin D1, cyclin E, CDK4, and the transcriptional activity of $\beta$-catenin/Tcf. Moreover, this alkaloid also potentiated tumor necrosis factor-a (TNF- $\alpha$ )-induced apoptosis and reduced the expression level of $\beta$-catenin and cyclin D1 in SW-480 cells [119].

Mechanistic studies on compounds 6 and 7 showed inhibition of the G0/G1 phase after $24 \mathrm{~h}$ exposure [83], with directed cell death absent mitochondrial alterations [120]. The antiproliferative effects of alkaloids 42-44 (Table 1) from Zanthoxylum capense in HCT-116 cell were shown to be mediated by apoptosis (Figure 1) [94].

Yang et al. (2010) showed that the arrest of the G1 phase in colon cancer cells and the induction of apoptosis are associated with the suppression of nuclear factor-kappaB (NF-kB) activation. The alkaloid also inhibited the phosphorylation/degradation of IkBa and the phosphorylation/translocation of p65. Furthermore, dauricine down-regulated the expression of various NF-kB-regulated genes, including genes involved in cell proliferation (COX-2, cyclin D1, and c-Myc), invasion (MMP-9 and ICAM-1), antiapoptosis (Bcl-2, XIAP, IAP1, and survivin), and angiogenesis (VEGF). The diversity of anticancer mechanisms was also noted with isostrychnopentamine (ISP) 2 , an indolomonoterpenic alkaloid that causes cell cycle arrest in the G2-M phase, and induces apoptosis by the translocation of phosphatidylserine from the inner layer to the outer layer of the plasma membrane, as well as by chromatin condensation, DNA fragmentation, and activation of the caspases 3 and 9 [91].

An experimental finding has illustrated a strong cytotoxic effect of oxymatrine 63 , an alkaloid isolated from Sophora flavescens in human colon cancer cells. The underlying mechanism was interfering with the overexpression of human telomerase reverse transcriptase and causing up-regulation of $h T E R T, c-m y c, p 53$, and mad1 [121]. The overall effect was concentration dependent (Figure 1) [122].

\section{Effects on Chemoresistance}

Cancer chemotherapy is limited by cellular drug resistance [123-126]. In this regard, different mechanisms have been implied for this resistance, including cell cycle arrest and repair [127], apoptosis [128], cancer stem cells [129], drug properties/nature [130], and metabolism of the drug [131]. Cell cycle arrest plays a crucial role in drug resistance to chemotherapy in various cancers [127]. Several studies have confirmed the involvement of checkpoint kinase (CHK1) in chemoresistance and even resistance in radiotherapy [132-134]. In the case of DNA damage, the complex cellular signaling network becomes activated and induces cell cycle arrest, thus facilitating DNA-repairing events or, in cases of extensive damage, such events trigger apoptosis [135-137].

Damage of the cellular DNA of any origin triggers the activation/upstream regulation of ATM(ataxia-telangiectasia mutated), and ATR(ATM- and Rad3-related) kinases coupled with the DNA-dependent protein kinase catalytic subunit $[135,138]$. These kinases lead to the translocation of components to the sites of damaged DNA and induce cell cycle progression by modulating effector kinases and checkpoint kinase like CHK1, and CHK2 [139]. The activation of checkpoints controlled by ATM/ATR-CHK1/CHK2 stalls cell cycle progression in the G1, S, or G2 phase [140]. G1 arrest is modulated by p53 through p21CIP1/WAF1 up-regulation [141], while in case of DNA damage, apoptosis charged over the situation [130]. In the course of events, p53 loses its regulatory action; as a result, the chemotherapy-induced DNA damage is unable to arrest the cancer cells in the G1 phase and thus trigger apoptosis. Indeed, to arrest the cell cycle in such cancer cells, following the genotoxic exposure, the $\mathrm{S}$ and $\mathrm{G} 2 / \mathrm{M}$ checkpoints are required to induce DNA repair before entry into mitosis (M phase). Different polysulfanes have shown cell cycle arrest in colorectal cancer [142-144]. 


\section{Conclusions and Future Prospects}

Based on increased cases of cancer and its status as a leading cause of disease worldwide, new effective treatments are required. Among the most common cancer treatments, chemotherapy is an essential tool in getting cancer under control and reducing or treating advanced or aggressive cancers. As noted in the current review, several alkaloids show anti-colon-cancer properties, being able to be cytotoxic against human colon cancer cells. The most exciting substances seem to be those able to act at the level of the checkpoints present at the G1/S and G2/M transitions, which account for the proper replication and division of DNA. These alkaloids hold great potential as novel therapeutic agents for the effective management of colon cancer.

Funding: This research received no external funding.

Acknowledgments: This work is supported by Taif University Researchers Supporting Program (Project Number: TURSP-2020/153) Taif University, Saudi Arabia.

Conflicts of Interest: The authors declare no conflict of interest.

$\begin{array}{ll}\text { Abbreviations } \\ \text { AchE } & \text { Acetylcholinesterase } \\ \text { ATM } & \text { Ataxia-telangiectasia mutated } \\ \text { BBR } & \text { Berberine } \\ \text { CHK1 } & \text { Checkpoint kinase } \\ \text { COVID-19 } & \text { Coronavirus disease 2019 } \\ \text { EC }_{50} \text { IC }_{50} \text { ROS } & \text { Half maximal effective concentration } \\ & \text { Half maximal inhibitory concentrationReactive oxygen species } \\ \text { TNF- } \alpha & \text { Tumor necrosis factor-alpha } \\ \text { WHO } & \text { World Health Organization }\end{array}$

\section{References}

1. Habli, Z.; Toumieh, G.; Fatfat, M.; Rahal, O.N.; Gali-Muhtasib, H. Emerging cytotoxic alkaloids in the battle against cancer: Overview of molecular mechanisms. Molecules 2017, 22, 250. [CrossRef] [PubMed]

2. Siegel, R.L.; Miller, K.D.; Jemal, A. Cancer statistics, 2017. CA Cancer J. Clin. 2017, 67, 7-30. [CrossRef] [PubMed]

3. Siegel, R.L.; Miller, K.D.; Fuchs, H.E.; Jemal, A. Cancer statistics, 2021. CA Cancer J. Clin. 2021, 71, 7-33. [CrossRef]

4. Nolen, S.C.; Evans, M.A.; Fischer, A.; Corrada, M.M.; Kawas, C.H.; Bota, D.A. Cancer-Incidence, prevalence and mortality in the oldest-old. A comprehensive review. Mech. Ageing Dev. 2017, 164, 113-126. [CrossRef] [PubMed]

5. Hurt, B.; Schulick, R.; Edil, B.; El Kasmi, K.C.; Barnett, C. Cancer-promoting mechanisms of tumor-associated neutrophils. Am. J. Surg. 2017, 214, 938-944. [CrossRef]

6. Siegel, R.L.; Miller, K.D.; Fedewa, S.A.; Ahnen, D.J.; Meester, R.G.S.; Barzi, A.; Jemal, A. Colorectal cancer statistics, 2017. CA Cancer J. Clin. 2017, 67, 177-193. [CrossRef]

7. Alyabsi, M.; Alhumaid, A.; Allah-Bakhsh, H.; Alkelya, M.; Aziz, M.A. Colorectal cancer in Saudi Arabia as the proof-of-principle model for implementing strategies of predictive, preventive, and personalized medicine in healthcare. EPMA J. 2020, 11, 119-131. [CrossRef]

8. Khan, H.; Patel, S.; A Kamal, M. Pharmacological and toxicological profile of harmane- $\beta$-Carboline alkaloid: Friend or foe. Curr. Drug Metab. 2017, 18, 853-857. [CrossRef]

9. Loren, A.W.; Mangu, P.B.; Beck, L.N.; Brennan, L.; Magdalinski, A.J.; Partridge, A.H.; Quinn, G.; Wallace, W.H.; Oktay, K. Fertility preservation for patients with cancer: American Society of Clinical Oncology clinical practice guideline update. J. Clin. Oncol. 2013, 31, 2500-2510. [CrossRef]

10. Andersen, B.L.; DeRubeis, R.J.; Berman, B.S.; Gruman, J.; Champion, V.L.; Massie, M.J.; Holland, J.C.; Partridge, A.H.; Bak, K.; Somerfield, M.R. Screening, assessment, and care of anxiety and depressive symptoms in adults with cancer: An American Society of Clinical Oncology guideline adaptation. J. Clin. Oncol. 2014, 32, 1605-1619. [CrossRef]

11. Kuppusamy, P.; Govindan, N.; Yusoff, M.M.; Ichwan, S.J.A. Proteins are potent biomarkers to detect colon cancer progression. Saudi J. Biol. Sci. 2017, 24, 1212-1221. [CrossRef] [PubMed]

12. Sato, K.; Tanaka, T.; Sato, J.; Shibata, E.; Nagai, Y.; Murono, K.; Yasuda, K.; Otani, K.; Nishikawa, T.; Tanaka, J.; et al. Usefulness of preoperative CT colonography for colon cancer. Asian J. Surg. 2017, 40, 438-443. [CrossRef] [PubMed]

13. Iqbal, A.; George, T.J. Randomized clinical trials in colon and rectal cancer. Surg. Oncol. Clin. N. Am. 2017, 26, 689-704. [CrossRef] [PubMed] 
14. El-Shami, K.; Oeffinger, K.C.; Erb, N.L.; Willis, A.; Bretsch, J.K.; Pratt-Chapman, M.L.; Cannady, R.S.; Wong, S.L.; Rose, J.; Barbour, A.L.; et al. American Cancer Society Colorectal Cancer Survivorship Care Guidelines. CA Cancer J. Clin. 2015, 65, 427-455. [CrossRef] [PubMed]

15. Al-Otaibi, J.S.; El Gogary, T.M. Synthesis of novel anthraquinones: Molecular structure, molecular chemical reactivity descriptors and interactions with DNA as antibiotic and anti-cancer drugs. J. Mol. Struct. 2017, 1130, 799-809. [CrossRef]

16. Arioka, M.; Takahashi-Yanaga, F.; Kubo, M.; Igawa, K.; Tomooka, K.; Sasaguri, T. Anti-tumor effects of differentiation-inducing factor-1 in malignant melanoma: GSK-3-mediated inhibition of cell proliferation and GSK-3-independent suppression of cell migration and invasion. Biochem. Pharmacol. 2017, 138, 31-48. [CrossRef] [PubMed]

17. Rock, C.L.; Doyle, C.; Demark-Wahnefried, W.; Meyerhardt, J.; Courneya, K.S.; Schwartz, A.L.; Bandera, E.V.; Hamilton, K.K.; Grant, B.; McCullough, M.; et al. Nutrition and physical activity guidelines for cancer survivors. CA Cancer J. Clin. 2012, 62, 242-274. [CrossRef] [PubMed]

18. Fan, B.-Y.; Li, Z.-R.; Ma, T.; Gu, Y.-C.; Zhao, H.-J.; Luo, J.-G.; Kong, L.-Y. Further screening of the resin glycosides in the edible water spinach and characterisation on their mechanism of anticancer potential. J. Funct. Foods 2015, 19 Pt A, 141-154. [CrossRef]

19. Farinha, P.; Pinho, J.O.; Matias, M.; Gaspar, M.M. Nanomedicines in the treatment of colon cancer: A focus on metallodrugs. Drug Deliv. Transl. Res. 2021, 12, 49-66. [CrossRef] [PubMed]

20. Amin, S.; Khan, H. Revival of natural products: Utilization of modern technologies. Curr. Bioact. Compd. 2016, 12, 103-106. [CrossRef]

21. Khan, H. Medicinal plants in light of history recognized therapeutic modality. J. Evid. Based Complementary Altern. Med. 2014, 19, 216-219. [CrossRef]

22. Khan, H. Brilliant future of phytomedicines in the light of latest technological developments. J. Phytopharm. 2015, 4, 58-60.

23. Khan, H.; Rengasamy, K.R.R.; Pervaiz, A.; Nabavi, S.M.; Atanasov, A.G.; Kamal, M.A. Plant-derived mPGES-1 inhibitors or suppressors: A new emerging trend in the search for small molecules to combat inflammation. Eur. J. Med. Chem. 2017, 153, 2-28. [CrossRef] [PubMed]

24. Khan, H.; Marya; Amin, S.; Kamal, M.A.; Patel, S. Flavonoids as acetylcholinesterase inhibitors: Current therapeutic standing and future prospects. Biomed. Pharmacother. 2018, 101, 860-870. [CrossRef] [PubMed]

25. Pervez, S.; Saeed, M.; Ali, M.S.; Fatima, I.; Khan, H. Antimicrobial and anti-oxidant potential of berberisinol, a new flavone from Berberis baluchistanica. Chem. Nat. Compd. 2018, accepted.

26. Nabavi, S.F.; Khan, H.; D’Onofrio, G.; Šamec, D.; Shirooie, S.; Dehpour, A.R.; Argüelles, S.; Habtemariam, S.; Sobarzo-Sanchez, E. Apigenin as neuroprotective agent: Of mice and men. Pharmacol. Res. 2018, 128, 359-365. [CrossRef]

27. Khan, H.; Amin, S.; Patel, S. Targeting BDNF modulation by plant glycosides as a novel therapeutic strategy in the treatment of depression. Life Sci. 2018, 196, 18-27. [CrossRef] [PubMed]

28. Amirkia, V.; Heinrich, M. Alkaloids as drug leads-A predictive structural and biodiversity-based analysis. Phytochem. Lett. 2014, 10, xlviii-liii. [CrossRef]

29. Qiu, S.; Sun, H.; Zhang, A.-H.; Xu, H.-Y.; Yan, G.-L.; Han, Y.; Wang, X.-J. Natural alkaloids: Basic aspects, biological roles, and future perspectives. Chin. J. Nat. Med. 2014, 12, 401-406. [CrossRef]

30. Khan, H.; Nabavi, S.M.; Sureda, A.; Mehterov, N.; Gulei, D.; Berindan-Neagoe, I.; Taniguchi, H.; Atanasov, A.G. Therapeutic potential of songorine, a diterpenoid alkaloid of the genus Aconitum. Eur. J. Med. Chem. 2017, accepted. [CrossRef] [PubMed]

31. Aniszewski, T. Chapter 3-Biology of alkaloids. In Alkaloids, 2nd ed.; Elsevier: Boston, MA, USA, 2015; pp. 195-258. [CrossRef]

32. Ain, Q.; Khan, H.; Mubarak, M.; Pervaiz, A. Plant alkaloids as antiplatelet agent: Drugs of future in the light of recent development. Front. Pharmacol. 2016, 7, 292. [CrossRef] [PubMed]

33. Kaleem, W.A.; Muhammad, N.; Khan, H.; Rauf, A.; Zia-ul-Haq, M.; Qayum, M.; Khan, A.Z.; Nisar, M.; Obaidullah. Antioxidant potential of cyclopeptide alkaloids isolated from Zizyphus oxyphylla. J. Chem. Soc. Pak. 2015, 36, 474-478.

34. Rehman, S.; Khan, H. Advances in antioxidant potential of natural alkaloids. Curr. Bioact. Compd. 2017, 13, 101-108. [CrossRef]

35. Kaleem, W.A.; Muhammad, N.; Qayum, M.; Khan, H.; Khan, A.; Aliberti, L.; De Feo, V. Antinociceptive activity of cyclopeptide alkaloids isolated from Ziziphus oxyphylla Edgew (Rhamnaceae). Fitoterapia 2013, 91, 154-158. [CrossRef] [PubMed]

36. Alakshmi, V.; Chandiran, R.; Velraj, M.; Hemalatha, S.; Jayakumari, S. Anti-anaphylactic and anti-inflammatory activities of a bioactive alkaloid from the root bark of Plumeria acutifolia Poir. Iran. J. Pharm. Res. IJPR 2011, 10, 525-533. [PubMed]

37. Khan, H. Alkaloids: Potential therapeuty modality in the management of asthma. J. Ayurvedic Herb. Med. $2015,1,3$.

38. Khattak, S.; Khan, H. Anti-cancer potential of phyto-alkaloids: A prospective review Curr. Cancer Ther. Rev. 2016, 12, 66-75. [CrossRef]

39. Pervaiz, A.; Khan, R.; Anwar, F.; Kamal, M.A.; Mushtaq, G.; Khan, H. Alkaloids: An emerging antibacterial modality against Methicillin Resistant Staphylococcus aureus. Curr. Pharm. Des. 2016, 22, 4420-4429. [CrossRef] [PubMed]

40. Khan, H.; Amin, S. ACE inhibition of plant alkaloids. Targeted approach for selective inhibition. Mini-Rev. Org. Chem. 2017, 14, 85-89. [CrossRef]

41. Burger, T.; Mokoka, T.; Fouché, G.; Steenkamp, P.; Steenkamp, V.; Cordier, W. Solamargine, a bioactive steroidal alkaloid isolated from Solanum aculeastrum induces non-selective cytotoxicity and P-glycoprotein inhibition. BMC Complementary Altern. Med. 2018, 18, 137. [CrossRef] 
42. Tauchen, J.; Huml, L.; Bortl, L.; Doskocil, I.; Jarosova, V.; Marsik, P.; Frankova, A.; Clavo Peralta, Z.M.; Chuspe Zans, M.-E.; Havlik, J. Screening of medicinal plants traditionally used in Peruvian Amazon for in vitro antioxidant and anticancer potential. Nat. Prod. Res. 2018, 1-4, accepted. [CrossRef] [PubMed]

43. Millimouno, F.M.; Dong, J.; Yang, L.; Li, J.; Li, X. Targeting apoptosis pathways in cancer and perspectives with natural compounds from mother nature. Cancer Prev. Res. 2014, 7, 1081-1107. [CrossRef] [PubMed]

44. Lu, J.-J.; Bao, J.-L.; Chen, X.-P.; Huang, M.; Wang, Y.-T. Alkaloids isolated from natural herbs as the anticancer agents. Evid. -Based Complementary Altern. Med. Ecam 2012, 2012, 485042. [CrossRef]

45. Nelson, R.L. The comparative clinical pharmacology and pharmacokinetics of vindesine, vincristine, and vinblastine in human patients with cancer. Pediatric Blood Cancer 1982, 10, 115-127. [CrossRef]

46. Glade, R.S.; Vinson, K.; Becton, D.; Bhutta, S.; Buckmiller, L.M. Management of complicated hemangiomas with vincristine/vinblastine: Quantitative response to therapy using MRI. Int. J. Pediatric Otorhinolaryngol. 2010, 74, 1221-1225. [CrossRef] [PubMed]

47. Mok, T.S.; Wu, Y.-L.; Thongprasert, S.; Yang, C.-H.; Chu, D.-T.; Saijo, N.; Sunpaweravong, P.; Han, B.; Margono, B.; Ichinose, Y. Gefitinib or carboplatin-paclitaxel in pulmonary adenocarcinoma. N. Engl. J. Med. 2009, 361, 947-957. [CrossRef] [PubMed]

48. Sandler, A.; Gray, R.; Perry, M.C.; Brahmer, J.; Schiller, J.H.; Dowlati, A.; Lilenbaum, R.; Johnson, D.H. Paclitaxel-carboplatin alone or with bevacizumab for non-small-cell lung cancer. N. Engl. J. Med. 2006, 355, 2542-2550. [CrossRef]

49. Parmar, M.; Ledermann, J.; Colombo, N.; Du Bois, A.; Delaloye, J.; Kristensen, G.; Wheeler, S.; Swart, A.; Qian, W.; Torri, V. Paclitaxel plus platinum-based chemotherapy versus conventional platinum-based chemotherapy in women with relapsed ovarian cancer: The ICON4/AGO-OVAR-2.2 trial. Lancet 2003, 361, 2099-2106.

50. Samadi, P.; Sarvarian, P.; Gholipour, E.; Asenjan, K.S.; Aghebati-Maleki, L.; Motavalli, R.; Hojjat-Farsangi, M.; Yousefi, M. Berberine: A novel therapeutic strategy for cancer. Iubmb Life 2020, 72, 2065-2079. [CrossRef]

51. Wang, W.-g.; Sun, W.-x.; Gao, B.-s.; Lian, X.; Zhou, H.-1. Cell cycle arrest as a therapeutic target of acute kidney injury. Curr. Protein Pept. Sci. 2017, 18, 1224-1231. [CrossRef]

52. Hicks, S.D.; Middleton, F.A.; Miller, M.W. Ethanol-induced methylation of cell cycle genes in neural stem cells. J. Neurochem. 2010, 114, 1767-1780. [CrossRef] [PubMed]

53. Komaki, S.; Schnittger, A. The spindle assembly checkpoint in arabidopsis is rapidly shut off during severe stress. Dev. Cell 2017, 43, 172-185.e175. [CrossRef] [PubMed]

54. DiPaola, R.S. To arrest or not to G2-M cell-cycle arrest. Clin. Cancer Res. 2002, 8, 3311-3314. [PubMed]

55. Bouwman, P.; Jonkers, J. The effects of deregulated DNA damage signalling on cancer chemotherapy response and resistance. Nat. Rev. Cancer 2012, 12, 587-598. [CrossRef] [PubMed]

56. Luo, L.; Gao, W.; Wang, J.; Wang, D.; Peng, X.; Jia, Z.; Jiang, Y.; Li, G.; Tang, D.; Wang, Y. Study on the mechanism of cell cycle checkpoint kinase 2 (CHEK2) gene dysfunction in chemotherapeutic drug resistance of triple negative breast cancer cells. Med. Sci. Monit. 2018, 15, 3176-3183. [CrossRef] [PubMed]

57. Lam, M.H.; Liu, Q.; Elledge, S.J.; Rosen, J.M. Chk1 is haploinsufficient for multiple functions critical to tumor suppression. Cancer Cell 2004, 6, 45-59. [CrossRef] [PubMed]

58. Zhou, J.; Chan, J.; Lambelé, M.; Yusufzai, T.; Stumpff, J.; Opresko, P.L.; Thali, M.; Wallace, S.S. NEIL3 repairs telomere damage during $S$ phase to secure chromosome segregation at mitosis. Cell Rep. 2017, 20, 2044-2056. [CrossRef]

59. Wang, J.Y.J. Cell responses to DNA damage. In Reference Module in Biomedical Sciences; Elsevier: Amsterdam, The Netherlands, 2017. [CrossRef]

60. Guleria, A.; Chandna, S. ATM kinase: Much more than a DNA damage responsive protein. DNA Repair 2016, 39, 1-20. [CrossRef]

61. Chen, H.; Tang, X.; Zhou, B.; Xu, N.; Zhou, Z.; Fang, K.; Wang, Y. BDE-47 and BDE-209 inhibit proliferation of Neuro-2a cells via inducing G1-phase arrest. Environ. Toxicol. Pharmacol. 2017, 50, 76-82. [CrossRef]

62. Xu, H.; Wang, Z.; Jin, S.; Hao, H.; Zheng, L.; Zhou, B.; Zhang, W.; Lv, H.; Yuan, Y. Dux4 induces cell cycle arrest at G1 phase through upregulation of p21 expression. Biochem. Biophys. Res. Commun. 2014, 446, 235-240. [CrossRef]

63. García, M.A.; Fueyo, R.; Martínez-Balbás, M.A. Chapter 10-Lysine Demethylases: Structure, Function, and Disfunction A2Binda, Olivier. In Chromatin Signaling and Diseases; Fernandez-Zapico, M.E., Ed.; Academic Press: Boston, MA, USA, 2016; pp. 179-194. [CrossRef]

64. Ahlander, J.; Bosco, G. The RB/E2F pathway and regulation of RNA processing. Biochem. Biophys. Res. Commun. 2009, 384, 280-283. [CrossRef] [PubMed]

65. Bertoli, C.; Skotheim, J.M.; de Bruin, R.A.M. Control of cell cycle transcription during G1 and S phases. Nat. Rev. Mol. Cell Biol. 2013, 14, 518-528. [CrossRef] [PubMed]

66. Chong, J.-L.; Wenzel, P.L.; Sáenz-Robles, M.T.; Nair, V.; Ferrey, A.; Hagan, J.P.; Gomez, Y.M.; Sharma, N.; Chen, H.-Z.; Ouseph, M. E2f1-3 switch from activators in progenitor cells to repressors in differentiating cells. Nature 2009, 462, 930-934. [CrossRef]

67. Weijts, B.G.; Bakker, W.J.; Cornelissen, P.W.; Liang, K.H.; Schaftenaar, F.H.; Westendorp, B.; De Wolf, C.A.; Paciejewska, M.; Scheele, C.L.; Kent, L. E2F7 and E2F8 promote angiogenesis through transcriptional activation of VEGFA in cooperation with HIF1. EMBO J. 2012, 31, 3871-3884. [CrossRef] [PubMed]

68. Pauwels, B.; Wouters, A.; Peeters, M.; Vermorken, J.B.; Lardon, F. Role of cell cycle perturbations in the combination therapy of chemotherapeutic agents and radiation. Future Oncol. 2010, 6, 1485-1496. [CrossRef] [PubMed] 
69. Tyson, J.J.; Novák, B. Chapter 14-Irreversible transitions, bistability and checkpoint controls in the eukaryotic cell cycle: A systems-level understanding A2-walhout. In Handbook of Systems Biology; Marian, A.J., Vidal, M., Dekker, J., Eds.; Academic Press: San Diego, CA, USA, 2013; pp. 265-285. [CrossRef]

70. Velez, A.M.A.; Howard, M.S. Tumor-suppressor genes, cell cycle regulatory checkpoints, and the skin. N. Am. J. Med. Sci. 2015, 7, 176-188. [CrossRef]

71. Brown, A.; Pospiech, J.; Eiwen, K.; Baker, D.J.; Moehrle, B.; Sakk, V.; Nattamai, K.; Vogel, M.; Grigoryan, A.; Geiger, H. The spindle assembly checkpoint is required for hematopoietic progenitor cell engraftment. Stem Cell Rep. 2017, 9, 1359-1368. [CrossRef] [PubMed]

72. Choi, H.J.; Zhu, B.T. Critical role of cyclin B1/Cdc2 up-regulation in the induction of mitotic prometaphase arrest in human breast cancer cells treated with 2-methoxyestradiol. Biochim. Biophys. Acta (BBA) Mol. Cell Res. 2012, 1823, 1306-1315. [CrossRef]

73. Trunnell, N.B.; Poon, A.C.; Kim, S.Y.; Ferrell, J.E. Ultrasensitivity in the Regulation of Cdc25C by Cdk1. Mol. Cell 2011, 41, 263-274. [CrossRef]

74. Vermeulen, K.; Van Bockstaele, D.R.; Berneman, Z.N. The cell cycle: A review of regulation, deregulation and therapeutic targets in cancer. Cell Prolif. 2003, 36, 131-149. [CrossRef]

75. McDonald, E.; El-Deiry, W.S. Cell cycle control as a basis for cancer drug development. Int. J. Oncol. 2000, 16, 871-957. [CrossRef]

76. Townson, J.L.; Chambers, A.F. Dormancy of solitary metastatic cells. Cell Cycle 2006, 5, 1744-1750. [CrossRef] [PubMed]

77. Orford, K.W.; Scadden, D.T. Deconstructing stem cell self-renewal: Genetic insights into cell-cycle regulation. Nat. Rev. Genet. 2008, 9, 115-128. [CrossRef] [PubMed]

78. Brandmaier, A.; Hou, S.-Q.; Shen, W.H. Cell Cycle Control by PTEN. J. Mol. Biol. 2017, 429, 2265-2277. [CrossRef]

79. Zhang, Y.; Chen, S.; Wei, C.; Rankin, G.O.; Ye, X.; Chen, Y.C. Flavonoids from Chinese bayberry leaves induced apoptosis and G1 cell cycle arrest via Erk pathway in ovarian cancer cells. Eur. J. Med. Chem. 2018, 147, 218-226. [CrossRef] [PubMed]

80. Xu, W.; Wang, B.; Yang, M.; Zhang, Y.; Xu, Z.; Yang, Y.; Cao, H.; Tao, L. Tebufenozide induces G1/S cell cycle arrest and apoptosis in human cells. Environ. Toxicol. Pharmacol. 2017, 49, 89-96. [CrossRef] [PubMed]

81. Whittaker, S.R.; Mallinger, A.; Workman, P.; Clarke, P.A. Inhibitors of cyclin-dependent kinases as cancer therapeutics. Pharmacol Ther. 2017, 173, 83-105. [CrossRef]

82. Sánchez-Martínez, C.; Gelbert, L.M.; Lallena, M.J.; de Dios, A. Cyclin dependent kinase (CDK) inhibitors as anticancer drugs. Bioorganic Med. Chem. Lett. 2015, 25, 3420-3435. [CrossRef]

83. Koduru, S.; Grierson, D.; Van de Venter, M.; Afolayan, A. Anticancer activity of steroid alkaloids isolated from Solanum aculeastrum. Pharm. Biol. 2007, 45, 613-618. [CrossRef]

84. Matkar, S.S.; Wrischnik, L.A.; Hellmann-Blumberg, U. Sanguinarine causes DNA damage and p53-independent cell death in human colon cancer cell lines. Chem. Biol. Interact. 2008, 172, 63-71. [CrossRef]

85. Lee, J.S.; Jung, W.-K.; Jeong, M.H.; Yoon, T.R.; Kim, H.K. Sanguinarine induces apoptosis of HT-29 human colon cancer cells via the regulation of Bax/Bcl-2 ratio and caspase-9-dependent pathway. Int. J. Toxicol. 2012, 31, 70-77. [CrossRef] [PubMed]

86. Ogasawara, M.; Matsubara, T.; Suzuki, H. Inhibitory effects of evodiamine on in vitro invasion and experimental lung metastasis of murine colon cancer cells. Biol. Pharm. Bull. 2001, 24, 917-920. [CrossRef]

87. Frédérich, M.; Tits, M.; Goffin, E.; Philippe, G.; Grellier, P.; De Mol, P.; Hayette, M.-P.; Angenot, L. In vitro and in vivo antimalarial properties of isostrychnopentamine, an indolomonoterpenic alkaloid from Strychnos usambarensis. Planta Med. 2004, 70, 520-525 [CrossRef] [PubMed]

88. Jiao, R.H.; Xu, S.; Liu, J.Y.; Ge, H.M.; Ding, H.; Xu, C.; Zhu, H.L.; Tan, R.X. Chaetominine, a cytotoxic alkaloid produced by endophytic Chaetomium sp. IFB-E015. Org. Lett. 2006, 8, 5709-5712. [CrossRef] [PubMed]

89. Shoeb, M.; MacManus, S.M.; Jaspars, M.; Trevidu, J.; Nahar, L.; Kong-Thoo-Lin, P.; Sarker, S.D. Montamine, a unique dimeric indole alkaloid, from the seeds of Centaurea montana (Asteraceae), and its in vitro cytotoxic activity against the CaCo2 colon cancer cells. Tetrahedron 2006, 62, 11172-11177. [CrossRef]

90. Kim, K.H.; Lee, I.K.; Piao, C.J.; Choi, S.U.; Lee, J.H.; Kim, Y.S.; Lee, K.R. Benzylisoquinoline alkaloids from the tubers of Corydalis ternata and their cytotoxicity. Bioorganic Med. Chem. Lett. 2010, 20, 4487-4490. [CrossRef]

91. Yang, Z.; Xiao, H.; Jin, H.; Koo, P.T.; Tsang, D.J.; Yang, C.S. Synergistic actions of atorvastatin with $\gamma$-tocotrienol and celecoxib against human colon cancer HT29 and HCT116 cells. Int. J. Cancer 2010, 126, 852-863. [CrossRef]

92. Huang, X.; Li, W.; Yang, X.-W. New cytotoxic quinolone alkaloids from fruits of Evodia rutaecarpa. Fitoterapia 2012, 83, 709-714. [CrossRef]

93. Weon, J.B.; Kim, C.Y.; Yang, H.J.; Ma, C.J. Neuroprotective compounds isolated from Cynanchum paniculatum. Arch. Pharmacal Res. 2012, 35, 617-621. [CrossRef]

94. Mansoor, T.A.; Borralho, P.M.; Luo, X.; Mulhovo, S.; Rodrigues, C.M.P.; Ferreira, M.-J.U. Apoptosis inducing activity of benzophenanthridine-type alkaloids and 2-arylbenzofuran neolignans in HCT116 colon carcinoma cells. Phytomedicine 2013, 20, 923-929. [CrossRef]

95. Kim, K.H.; Moon, E.; Kang, K.S.; Kim, S.Y.; Choi, S.U.; Lee, K.R. Alkaloids from Acorus gramineus rhizomes and their biological activity. J. Braz. Chem. Soc. 2015, 26, 3-8.

96. Zhang, Y.; Guo, L.; Yang, G.; Guo, F.; Di, Y.; Li, S.; Chen, D.; Hao, X. New vobasinyl-ibogan type bisindole alkaloids from Tabernaemontana corymbosa. Fitoterapia 2015, 100, 150-155. [CrossRef] [PubMed] 
97. Yaffe, P.B.; Power Coombs, M.R.; Doucette, C.D.; Walsh, M.; Hoskin, D.W. Piperine, an alkaloid from black pepper, inhibits growth of human colon cancer cells via G1 arrest and apoptosis triggered by endoplasmic reticulum stress. Mol. Carcinog. 2015, 54, 1070-1085. [CrossRef] [PubMed]

98. Madhavi, B.B.; Nath, A.R.; Banji, D.; Madhu, M.N.; Ramalingam, R.; Swetha, D. Extraction, identification, formulation and evaluation of piperine in alginate beads. Int. J. Pharm. Pharm. Sci. 2009, 1, 156-161.

99. Paterna, A.; Gomes, S.E.; Borralho, P.M.; Mulhovo, S.; Rodrigues, C.M.; Ferreira, M.-J.U. Vobasinyl-Iboga Alkaloids from Tabernaemontana elegans: Cell Cycle Arrest and Apoptosis-Inducing Activity in HCT116 Colon Cancer Cells. J. Nat. Prod. 2016, 79, 2624-2634. [CrossRef]

100. Liu, Y.-P.; Yue, G.G.-L.; Lee, J.K.-M.; Feng, T.; Zhao, Y.-L.; Li, Y.; Lau, C.B.-S.; Luo, X.-D. Melodinine V, an antitumor bisindole alkaloid with selective cytotoxicity from Melodinus henryi. Bioorganic Med. Chem. Lett. 2016, 26, 4895-4898. [CrossRef] [PubMed]

101. Singh, S.; Verma, M.; Malhotra, M.; Prakash, S.; Singh, T.D. Cytotoxicity of alkaloids isolated from Argemone mexicana on SW480 human colon cancer cell line. Pharm. Biol. 2016, 54, 740-745. [CrossRef]

102. Arun, A.; Patel, O.P.S.; Saini, D.; Yadav, P.P.; Konwar, R. Anti-colon cancer activity of Murraya koenigii leaves is due to constituent murrayazoline and O-methylmurrayamine A induced mTOR/AKT downregulation and mitochondrial apoptosis. Biomed. Pharmacother. 2017, 93, 510-521. [CrossRef]

103. Rasol, N.E.; Ahmad, F.B.; Lim, X.-Y.; Chung, F.F.-L.; Leong, C.-O.; Mai, C.-W.; Bihud, N.V.; Zaki, H.M.; Ismail, N.H. Cytotoxic lactam and naphthoquinone alkaloids from roots of Goniothalamus lanceolatus Miq. Phytochem. Lett. 2018, 24, 51-55. [CrossRef]

104. Van Hattum, A.H.; Pinedo, H.M.; Schlüper, H.M.; Erkelens, C.A.; Tohgo, A.; Boven, E. The activity profile of the hexacyclic camptothecin derivative DX-8951f in experimental human colon cancer and ovarian cancer. Biochem. Pharmacol. 2002, 64, 1267-1277. [CrossRef]

105. Sunassee, S.N.; Ransom, T.; Henrich, C.J.; Beutler, J.A.; Covell, D.G.; McMahon, J.B.; Gustafson, K.R. Steroidal alkaloids from the marine sponge Corticium niger that inhibit growth of human colon carcinoma cells. J. Nat. Prod. 2014, 77, 2475-2480. [CrossRef] [PubMed]

106. Diana, P.; Carbone, A.; Barraja, P.; Montalbano, A.; Martorana, A.; Dattolo, G.; Gia, O.; Dalla Via, L.; Cirrincione, G. Synthesis and antitumor properties of 2, 5-bis ( $3^{\prime}$-indolyl) thiophenes: Analogues of marine alkaloid nortopsentin. Bioorganic Med. Chem. Lett. 2007, 17, 2342-2346. [CrossRef] [PubMed]

107. Luo, W.; Liu, J.; Li, J.; Zhang, D.; Liu, M.; Addo, J.K.; Patil, S.; Zhang, L.; Yu, J.; Buolamwini, J.K. Anti-cancer effects of JKA97 are associated with its induction of cell apoptosis via a Bax-dependent and p53-independent pathway. J. Biol. Chem. 2008, 283, 8624-8633. [CrossRef] [PubMed]

108. Srinivas, C.; Kumar, C.N.S.P.; Raju, B.C.; Rao, V.J.; Naidu, V.; Ramakrishna, S.; Diwan, P.V. First stereoselective total synthesis and anticancer activity of new amide alkaloids of roots of pepper. Bioorganic Med. Chem. Lett. 2009, 19, 5915-5918. [CrossRef] [PubMed]

109. Alam, M.S.; Liu, L.; Lee, D.U. Cytotoxicity of new 5-phenyl-4,5-dihydro-1,3,4-thiadiazole analogues. Chem. Pharm. Bull. 2011, 59, 1413-1416. [CrossRef] [PubMed]

110. Guaman Ortiz, L.M.; Tillhon, M.; Parks, M.; Dutto, I.; Prosperi, E.; Savio, M.; Arcamone, A.G.; Buzzetti, F.; Lombardi, P.; Scovassi, A.I. Multiple effects of berberine derivatives on colon cancer cells. BioMed Res. Int. 2014, 2014, 924585. [CrossRef]

111. Guamán Ortiz, L.M.; Croce, A.L.; Aredia, F.; Sapienza, S.; Fiorillo, G.; Syeda, T.M.; Buzzetti, F.; Lombardi, P.; Scovassi, A.I. Effect of new berberine derivatives on colon cancer cells. Acta Biochim. Et Biophys. Sin. 2015, 47, 824-833. [CrossRef]

112. Paterna, A.; Borralho, P.M.; Gomes, S.E.; Mulhovo, S.; Rodrigues, C.M.; Ferreira, M.-J.U. Monoterpene indole alkaloid hydrazone derivatives with apoptosis inducing activity in human HCT116 colon and HepG2 liver carcinoma cells. Bioorganic Med. Chem. Lett. 2015, 25, 3556-3559. [CrossRef]

113. Liu, J.; He, Y.; Zhang, D.; Cai, Y.; Zhang, C.; Zhang, P.; Zhu, H.; Xu, N.; Liang, S. In vitro anticancer effects of two novel phenanthroindolizidine alkaloid compounds on human colon and liver cancer cells. Mol. Med. Rep. 2017, 16, 2595-2603. [CrossRef]

114. Tillhon, M.; Guamán-Ortiz, L.; Lombardi, P.; Scovassi, A. Berberine: New perspectives for old remedies. Biochem. Pharmacol. 2012, 84, 1260-1267. [CrossRef]

115. Malumbres, M.; Sotillo, R.o.; Santamaría, D.; Galán, J.; Cerezo, A.; Ortega, S.; Dubus, P.; Barbacid, M. Mammalian cells cycle without the D-type cyclin-dependent kinases Cdk4 and Cdk6. Cell 2004, 118, 493-504. [CrossRef] [PubMed]

116. Mushtaq, M.; Gaza, H.V.; Kashuba, E.V. Role of the RB-Interacting Proteins in Stem Cell Biology. Adv. Cancer Res. 2016, 131, 133-157. [CrossRef] [PubMed]

117. Lee, J.-J.; Lee, J.-H.; Gu, M.J.; Han, J.-H.; Cho, W.-K.; Ma, J.Y. Agastache rugosa Kuntze extract, containing the active component rosmarinic acid, prevents atherosclerosis through up-regulation of the cyclin-dependent kinase inhibitors p21WAF1/CIP1 and p27KIP1. J. Funct. Foods 2017, 30, 30-38. [CrossRef]

118. Huang, S.; Chen, C.S.; Ingber, D.E. Control of cyclin D1, p27Kip1, and cell cycle progression in human capillary endothelial cells by cell shape and cytoskeletal tension. Mol. Biol. Cell 1998, 9, 3179-3193. [CrossRef] [PubMed]

119. Wang, H.; Wang, L.; Xie, Z.; Zhou, S.; Li, Y.; Zhou, Y.; Sun, M. Nitric oxide (NO) and NO synthases (NOS)-based targeted therapy for colon cancer. Cancers 2020, 12, 1881. [CrossRef]

120. Friedman, M. Chemistry and anticarcinogenic mechanisms of glycoalkaloids produced by eggplants, potatoes, and tomatoes. $J$. Agric. Food Chem. 2015, 63, 3323-3337. [CrossRef] [PubMed] 
121. Zou, J.; Ran, Z.H.; Xu, Q.; Xiao, S.D. Experimental study of the killing effects of oxymatrine on human colon cancer cell line SW1116. Chin. J. Dig. Dis. 2005, 6, 15-20. [CrossRef]

122. Aung, T.N.; Qu, Z.; Kortschak, R.D.; Adelson, D.L. Understanding the effectiveness of natural compound mixtures in cancer through their molecular mode of action. Int. J. Mol. Sci. 2017, 18, 656. [CrossRef]

123. Zhitomirsky, B.; Assaraf, Y.G. Lysosomes as mediators of drug resistance in cancer Drug Resist. Updates 2016, 24, $23-33$.

124. Gonen, N.; Assaraf, Y. Antifolates in cancer therapy: Structure, activity and mechanisms of drug resistance. Drug Resist. Update 2012, 15, 183-210. [CrossRef]

125. Gottesman, M.; Lavi, O.; Hall, M.; Gillet, J. Toward a better understanding of the complexity of cancer drug resistance. Annu. Rev. Pharm. Toxicolgy 2016, 56, 85-102. [CrossRef] [PubMed]

126. Wijdeven, R.; Pang, B.; Assaraf, Y.; Neefjes, J. Old drugs, novel ways out: Drug resistance toward cytotoxic chemotherapeutics. Drug Resist. Updates 2016, 28, 65-81. [CrossRef] [PubMed]

127. Santoro, R.; Carbone, C.; Piro, G.; Chiao, P.J.; Melisi, D. TAK-ing aim at chemoresistance: The emerging role of MAP3K7 as a target for cancer therapy. Drug Resist. Updates 2017, 33-35, 36-42. [CrossRef] [PubMed]

128. Soengas, M.S.; Lowe, S.W. Apoptosis and melanoma chemoresistance. Oncogene 2003, 22, 3138-3151. [CrossRef]

129. Abdullah, L.N.; Chow, E.K.-H. Mechanisms of chemoresistance in cancer stem cells. Clin. Transl. Med. 2013, 2, 3-12. [CrossRef]

130. Sakthivel, K.M.; Hariharan, S. Regulatory players of DNA damage repair mechanisms: Role in cancer chemoresistance. Biomed. Pharmacother. 2017, 93, 1238-1245. [CrossRef]

131. Fodale, V.; Pierobon, M.; Liotta, L.; Petricoin, E. Mechanism of cell adaptation: When and how do cancer cells develop chemoresistance? Cancer J. 2011, 17, 89-95. [CrossRef]

132. Frosina, G. DNA repair and resistance of gliomas to chemotherapy and radiotherapy. Mol. Cancer Res. 2009, 7, 989-999. [CrossRef]

133. Ashwell, S.; Zabludoff, S. DNA damage detection and repair pathways-Recent advances with inhibitors of checkpoint kinases in cancer therapy. Clin. Cancer Res. 2008, 14, 4032-4037. [CrossRef]

134. Eyler, C.E.; Rich, J.N. Survival of the fittest: Cancer stem cells in therapeutic resistance and angiogenesis. J. Clin. Oncol. 2008, 26, 2839-2845. [CrossRef]

135. Friedberg, E.C.; Walker, G.C.; Siede, W.; Wood, R.D. DNA Repair and Mutagenesis; American Society for Microbiology Press: Washington, DC, USA, 2005.

136. Akasaka, T.; Tsujii, M.; Kondo, J.; Hayashi, Y.; Ying, J.; Lu, Y.; Kato, M.; Yamada, T.; Yamamoto, S.; Inoue, T. 5-FU resistance abrogates the amplified cytotoxic effects induced by inhibiting checkpoint kinase 1 in p53-mutated colon cancer cells. Int. J. Oncol. 2015, 46, 63-70. [CrossRef] [PubMed]

137. Oren, M.; Damalas, A.; Gottlieb, T.; Michael, D.; Taplick, J.; LEAL, J.F.; Maya, R.; Moas, M.; Seger, R.; Taya, Y. Regulation of p53. Ann. N. Y. Acad. Sci. 2002, 973, 374-383. [CrossRef] [PubMed]

138. Matsuoka, S.; Ballif, B.A.; Smogorzewska, A.; McDonald, E.R.; Hurov, K.E.; Luo, J.; Bakalarski, C.E.; Zhao, Z.; Solimini, N.; Lerenthal, Y. ATM and ATR substrate analysis reveals extensive protein networks responsive to DNA damage. Science 2007, 316, 1160-1166. [CrossRef] [PubMed]

139. Jazayeri, A.; Falck, J.; Lukas, C.; Bartek, J.; Smith, G.C.; Lukas, J.; Jackson, S.P. ATM-and cell cycle-dependent regulation of ATR in response to DNA double-strand breaks. Nat. Cell Biol. 2006, 8, 37-45. [CrossRef] [PubMed]

140. Manic, G.; Obrist, F.; Sistigu, A.; Vitale, I. Trial Watch: Targeting ATM-CHK2 and ATR-CHK1 pathways for anticancer therapy. Mol. Cell. Oncol. 2015, 2, e1012976. [CrossRef] [PubMed]

141. Taylor, B.F.; McNeely, S.C.; Miller, H.L.; Lehmann, G.M.; McCabe, M.J. p53 suppression of arsenite-induced mitotic catastrophe is mediated by p21CIP1/WAF1. J. Pharmacol. Exp. Ther. 2006, 318, 142-151. [CrossRef] [PubMed]

142. Vousden, K.H.; Prives, C. Blinded by the light: The growing complexity of p53. Cell 2009, 137, 413-431. [CrossRef] [PubMed]

143. Schmitt, C.A. Cellular senescence and cancer treatment. Biochim. Biophys. Acta (BBA) Rev. Cancer 2007, 1775, 5-20. [CrossRef]

144. Bharti, A.C.; Vishnoi, K.; Singh, S.M.; Aggarwal, B.B. Chapter 1-Pathways linked to cancer chemoresistance and their targeting by nutraceuticals. In Role of Nutraceuticals in Cancer Chemosensitization; Elsevier: Amsterdam, The Netherlands, 2018; Volume 2, pp. $1-30$ 